\title{
Modelling land system evolution and dynamics of terrestrial carbon stocks in the Luanhe River Basin, China: a scenario analysis of trade-offs and synergies between sustainable development goals
}

\author{
Jiren $\mathrm{Xu}^{1} \odot$ - Fabrice G. Renaud ${ }^{1} \cdot$ Brian Barrett $^{2}$ \\ Received: 8 March 2021 / Accepted: 4 July 2021 / Published online: 16 July 2021 \\ (c) Crown 2021
}

\begin{abstract}
A more holistic understanding of land use and land cover (LULC) will help minimise trade-offs and maximise synergies, and lead to improved future land use management strategies for the attainment of Sustainable Development Goals (SDGs). However, current assessments of future LULC changes rarely focus on the multiple demands for goods and services, which are related to the synergies and trade-offs between SDGs and their targets. In this study, the land system (combinations of land cover and land use intensity) evolution trajectories of the Luanhe River Basin (LRB), China, and major challenges that the LRB may face in 2030, were explored by applying the CLUMondo and InVEST models. The results indicate that the LRB is likely to experience agricultural intensification and urban growth under all four scenarios that were explored. The cropland intensity and the urban growth rate were much higher under the historical trend (Trend) scenario compared to those with more planning interventions (Expansion, Sustainability, and Conservation scenarios). Unless the forest area and biodiversity conservation targets are implemented (Conservation scenario), the forest areas are projected to decrease by 2030. The results indicate that water scarcity in the LRB is likely to increase under all scenarios, and the carbon storage will increase under the Conservation scenario but decrease under all other scenarios by 2030. Our methodological framework and findings can guide regional sustainable development in the LRB and other large river basins in China, and will be valuable for policy and planning purposes to the pursuance of SDGs at the sub-national scale.
\end{abstract}

Keywords Land system · Terrestrial carbon stocks · Luanhe River Basin · Sustainable development goals

\section{Introduction}

Natural resources, particularly land use and land cover (LULC) types and their associated changes, are central to sustainable development issues (Turner 1997). With continued societal and economic development, various human activities have significantly influenced the Earth's surface

Handledby Osamu Saito, Institute for Global Environmental Strategies, Japan.

Jiren Xu

jiren.xu@glasgow.ac.uk; jiren.xu@ hotmail.com

1 School of Interdisciplinary Studies, University of Glasgow, Dumfries, UK

2 School of Geographical and Earth Sciences, University of Glasgow, Glasgow, UK to satisfy societal demand for food and living space, with considerable environmental consequences (Ellis et al. 2010; Malek et al. 2018), in which LULC is one of the most significant indicators of such impacts (Lambin and Meyfroidt 2011). LULC directly affects the status and integrity of ecosystems and their capacity to supply ecosystem services (Nelson et al. 2009). The United Nations General Assembly endorsed 17 sustainable development goals (SDGs) to assess and address the major challenges and threats of various social-ecological systems by 2030 . These goals are related to ecosystem services (ES) and natural capital valuation (Barnaud et al. 2018; Costanza et al. 2014; Griggs et al. 2013), which are also affected by LULC. The 17 SDGs do not act individually or exist independently from each other, and some goals are thought to be mutually reinforcing or counter-acting (Nilsson et al. 2016a, b). The achievement of the SDGs crucially depends on maximising such synergies 
and resolving the existing trade-offs between various goals in different context strategies (Bowen et al. 2017; Kroll et al. 2019; Pradhan et al. 2017; Zhao et al. 2021). Most previous research addresses synergies and trade-offs between goals and between targets at the national scale, although such issues are also relevant at the sub-national scale (Hutton et al. 2018; Nerini et al. 2018; Scherer et al. 2018; Singh et al. 2018a). Therefore, a more holistic understanding of the complexities of future LULC associated with human demand for diverse ecosystem services and the potential trade-offs and synergies between SDGs is essential for providing a reference for decision making for sustainable development at the sub-national scale.

Because of complex driving factors and significant variations in LULC, it is challenging to predict LULC precisely (Verburg et al. 2004). LULC modelling is frequently utilised to understand and predict land system evolution trajectories considering socio-economic development and environmental protection policies at different scales (Alcamo and Schaldach 2006; Li et al. 2017b; Verburg et al. 2004, 2002). Many research groups have used simulation models to explore how future LULC changes would occur under various scenarios from a multidisciplinary perspective. Models such as the CLUE-S (Kucsicsa et al. 2019; Verburg and Overmars 2007), FORE-SCE (Rajib et al. 2016; Sohl et al. 2007), Markov chain and cellular automata analysis models (Hyandye and Martz 2017; Singh et al. 2018b) and agentbased models (Matthews et al. 2007; Parker et al. 2008) have been widely used to simulate LULC change at the local or river basin scales. Some large-scale land use models such as the LandSHIFT model (Alcamo and Schaldach 2006), GLOBIOM integrated assessment model (Ermolieva et al. 2015), and IMAGE model (Strengers et al. 2004) are used in regional or global LULC change simulations. These models typically simulate changes in mutually exclusive classes related to their land covers, such as forests, cropland, and built-up land. However, many land use changes do not directly affect the land cover at a location but instead relate to the land use intensity, while more nuanced changes between land use intensity and land management changes can have strong implications for ecological and environmental sustainability (Van Asselen and Verburg 2013). Yet, land uses can change in their extent but also in their intensity, thus allowing for multiple different change trajectories in response to an increase in demand. Moreover, most models are driven by demands for agricultural products and built-up areas, though the multiple non-material demands for afforestation and biodiversity protection will also affect the land system changes (DeFries and Rosenzweig 2010; Eitelberg et al. 2016). To overcome these constraints, a land systembased approach, which captures both land cover and land use at the landscape level, was proposed for land change modelling (Van Asselen and Verburg 2012). CLUMondo provides an innovative approach to simulate changes in land systems driven by various demands for commodities or services (Van Asselen and Verburg 2013). The integration of land management and land cover aspects allows the CLUMondo model to synchronously address multiple land system trajectories upon changes in driving factors. The CLUMondo model can not only allocate land system changes as determined by the regional demands of land cover types or different land use intensity, but also considers the local spatial preference, area restrictions, and competition between land systems. In CLUMondo, each good or service can be supplied by multiple land systems, and one land system can supply multiple goods or services simultaneously (Van Asselen and Verburg 2013).

In this study, we carry out scenario simulations based on the shared socio-economic pathways (SSPs) and regional policy and environmental conservation targets. The SSPs provide a framework for developing new socio-economic scenarios for global climate change studies and assessments of the broader sustainable development context (Ebi et al. 2014; O'Neill et al. 2014; Van Vuuren et al. 2014). The SSP framework is a critical component in the ongoing Intergovernmental Panel on Climate Change (IPCC) assessment of global climate change (O'Neill et al. 2016). The SSP framework has five scenarios. SSP1 is a sustainable pathway that is people-oriented and where land use is strongly regulated (Van Vuuren et al. 2017). International cooperation for climate change mitigation starts early (after 2020), and all land use emissions are priced at the level of carbon prices in the energy sector. SSP2 (Business-as-Usual) is a middle pathway between SSP1 and SSP3 that captures moderate challenges to mitigation and adaptation, with historically consistent trends in technological, economic and societal progress (Fricko et al. 2017). SSP3 is a regional rivalry pathway contrary to global cooperation. Countries focus on achieving energy and food security goals within their regions at the expense of broader-based development. Population growth is high in developing countries and low in industrialised countries. Environmental concerns remain a low international priority, resulting in substantial environmental degradation in some regions. Land use change is lightly regulated (Fujimori et al. 2017). SSP4 is a divided pathway in which inequality and stratification are increasing both across and within countries (Calvin et al. 2017). SSP5 is a fossil-fuelled development pathway in which the global economy grows rapidly, but people face severe mitigation challenges (Kriegler et al. 2017). Land use change is incompletely regulated, i.e. tropical deforestation continues, although at slowly declining rates over time. Crop yields are rapidly increasing. Unhealthy diets with high animal shares and high waste prevail (Popp et al. 2017).

As the most afforested river basin in North China and the main water source of Tianjin city, the fourth-largest urban 
area of China with a population of approximately 15 million, the Luanhe River Basin (LRB) plays a vital role in regional sustainable development (Yang et al. 2019). The LRB features marked afforestation over its upper basin since 1999, not only protecting Beijing from sandstorms originating from the Mongolian Plateau but also contributing significantly to soil and water conservation and carbon removal for climate change mitigation. To understand how the economic development, environmental protection and planning or policies will impact on future LULC and the attainment of the specify SDGs in the LRB, this study aims to analyse future LULC changes in the LRB to 2030 under different development scenarios that represent various socioeconomic pathways and environmental conservation targets, and assess potential trade-offs and synergies based on these scenarios. The impact of these changes on the amount of carbon stored in the landscape is also calculated along with assessing the related implications for environmental management and planning purposes in pursuance of the SDGs.

\section{Materials and methods}

\section{Study area}

The LRB, covering a total area of approximately 45,000 $\mathrm{km}^{2}$, is located across a semi-arid area of North China $\left(39^{\circ} 10^{\prime}-42^{\circ} 30^{\prime} \mathrm{N}, 115^{\circ} 30^{\prime}-119^{\circ} 15^{\prime} \mathrm{E}\right)$ (Fig. 1). It is an important ecological barrier to alleviate the effects of sandstorms from Mongolia Plateau and an important water resource for the Beijing-Tianjin-Hebei (BTH) region. The LRB is composed of three main types of terrain: plateau, mountainous area, and plain. The terrain inclines from northwest to southeast, and the average elevation is $766 \mathrm{~m}$. It is situated in a typical temperate continental monsoonal zone with a semi-arid climate (Zhang et al. 2019), with an annual average temperature and precipitation during $1982-2015$ of $7.0 \pm 2.6^{\circ} \mathrm{C}$ and $488.4 \pm 80.7 \mathrm{~mm}$, respectively (Wu et al. 2020). The temporal differences in precipitation distribution are significant, with heavy rainfall and relatively high temperatures in summer and less rainfall and lower temperatures in winter. The precipitation concentrates during the summer, which is about $200-550 \mathrm{~mm}$, accounting for $66-76 \%$ of the annual precipitation (Geng

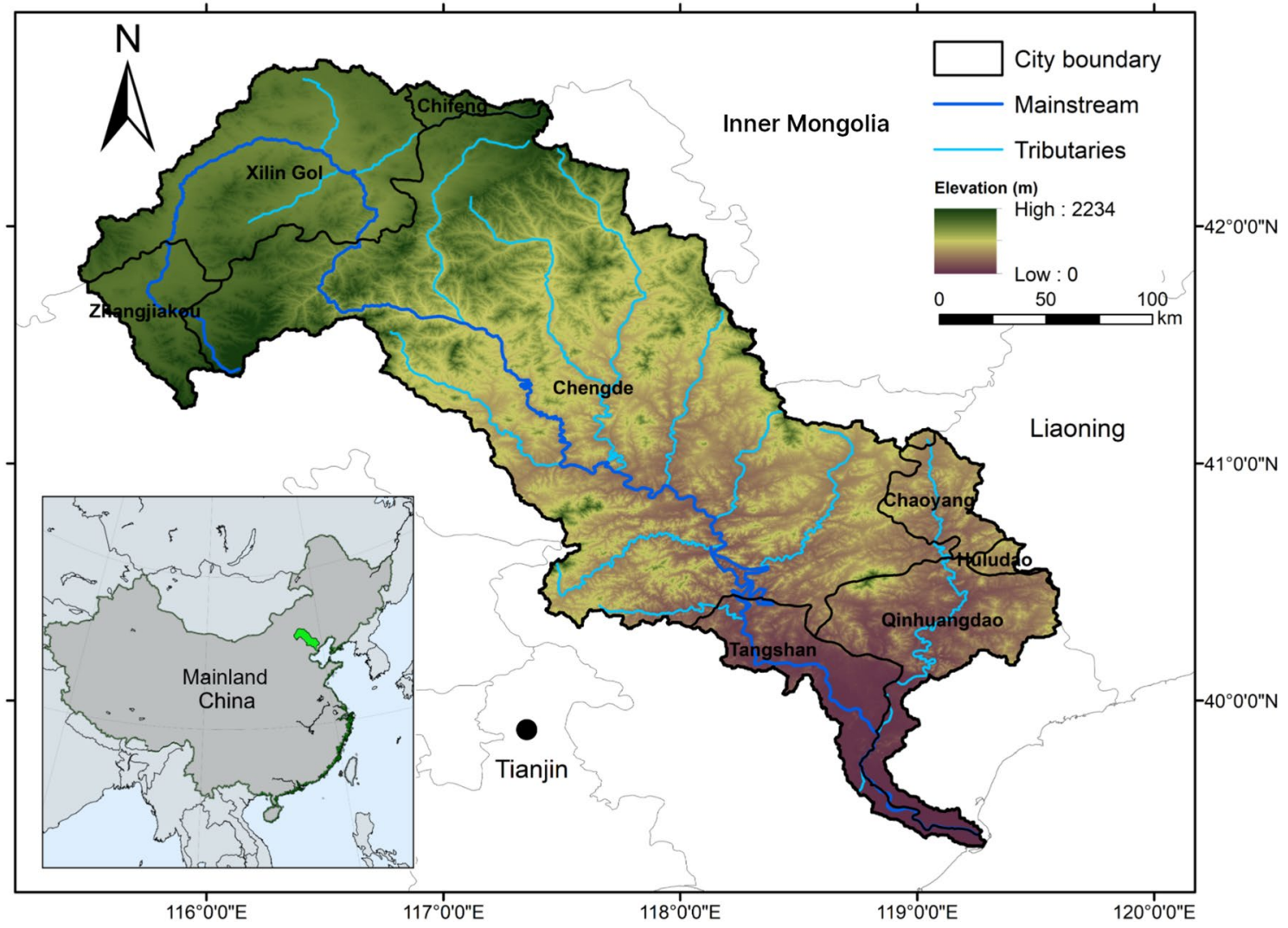

Fig. 1 Location of the Luanhe River Basin. The mainstream of the Luanhe river is displayed in dark blue, and its associated tributaries in light blue 
et al. 2020). The upper reaches region is mainly covered by grassland, and the middle-lower reaches region is mainly covered by temperate forests, while the croplands and urban areas are located towards the eastern plains. The population in the LRB is approximately 5.4 million, with a density of 122 residents per $\mathrm{km}^{2}$ (Bi et al. 2018).

\section{CLUMondo framework}

The research was conducted in three steps. First, land systems of the LRB in the years 2000 and 2015 were mapped by integrating different datasets related to human-environment attributes. Then, the relationship between the land systems and local explanatory factors was calculated for the initial year (2000). Second, the CLUMondo model (Van Asselen and Verburg 2013) was parameterised and calibrated based on the 2015 land systems map. Finally, changes in the land systems from 2015 to 2030 were simulated under different scenarios, including alternative sets of demands for commodities and services and represented different pathways on managing LRB's land resources. The overall approach is illustrated in Fig. 2.

\section{Land system classification}

The land system classification is based on three main classification factors: (1) land use and cover, (2) livestock, and (3) agricultural intensity. Land use/cover represents the landscape's composition, while livestock and agricultural intensity data represent important characteristics of land management and farming systems. Each variable's classification threshold was arbitrarily determined by the natural breaks in the variable distribution (van Asselen and Verburg 2012).

This study used the China National Land Use and Cover Change (CNLUCC) dataset (Liu et al. 2014; Xu et al. 2018b) from the Resources and Environmental Sciences Data Center of the Chinese Academy of Sciences. There are six land use and land cover categories, including farmland, forestland, grassland, water, urban land, and unused land in CNLUCC. The classification accuracy of CNLUCC was validated using nationwide field verification. Approximately, $10 \%$ of China's counties were randomly extracted, and all polygons in each county were validated through manual or visual interpretation to calculate the accuracy. The classification accuracies of selected polygons were more than $94.3 \%$ (Xu et al. 2018b).

In this study, considering the data availability, we used the demand for crops, livestock, overall built-up land areas and overall forest areas as the drivers for the CLUMondo simulations. Similar to Liu et al. (2017), the land system
Fig. 2 Land system change simulation workflow

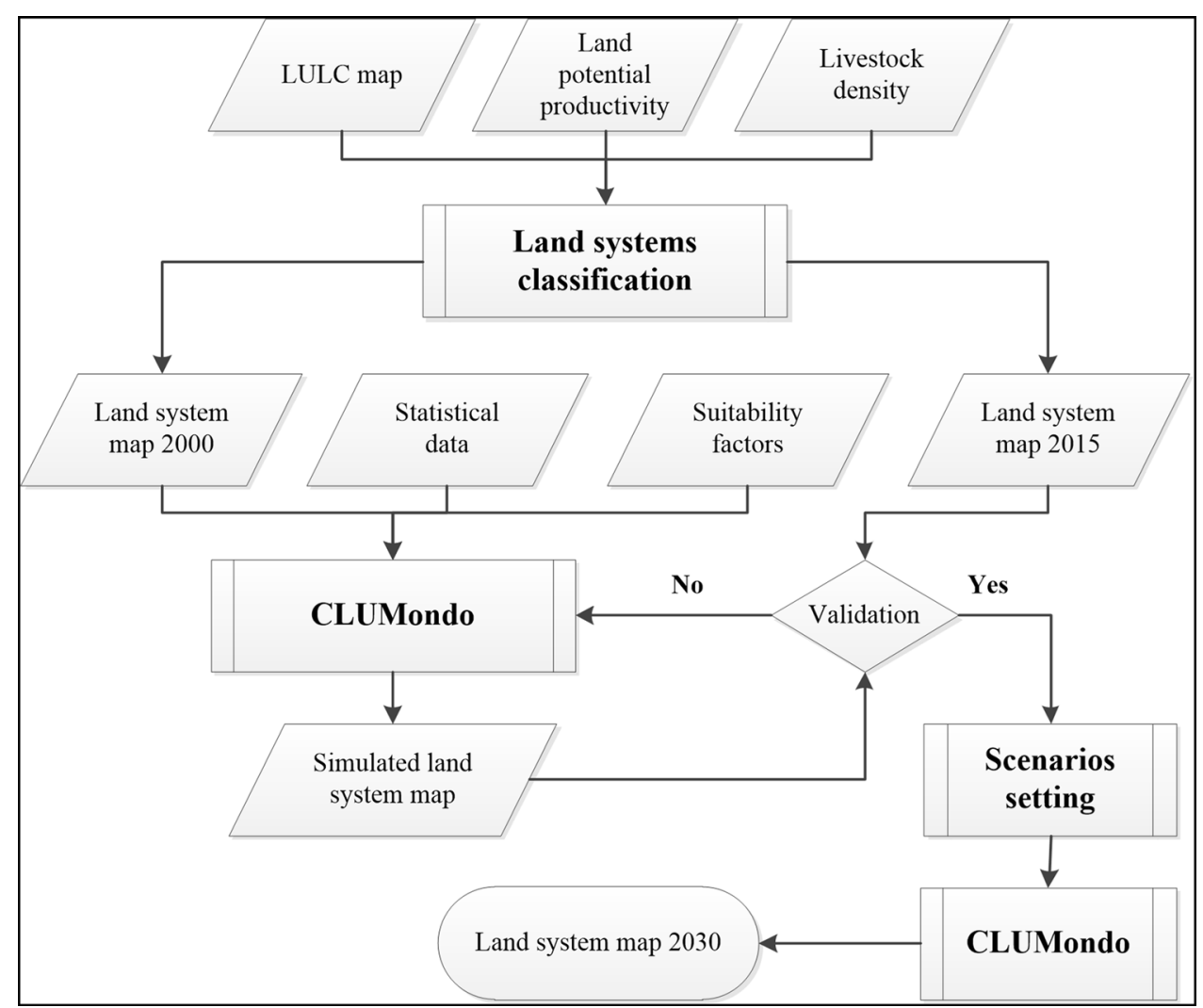


Table 1 Data used for land system delineation and the explanatory variables

\begin{tabular}{|c|c|c|c|c|}
\hline Data application & Main category & Factors & Unit & Source \\
\hline \multirow[t]{3}{*}{ Delineate Land systems } & Land use/cover data & & Class & \multirow{2}{*}{$\begin{array}{l}\text { Resources and Environmen- } \\
\text { tal Sciences Data Center, } \\
\text { Chinese Academy of Sciences } \\
\text { (RESDC, http://www.resdc. } \\
\text { cn/) }\end{array}$} \\
\hline & Potential cropland production & & $\begin{array}{l}\text { Index }(0-1) \\
\text { normalized from } \\
\text { tons } / \mathrm{km}^{2}\end{array}$ & \\
\hline & Livestock density & & heads $/ \mathrm{km}^{2}$ & $\begin{array}{l}\text { Global Distribution of Livestock } \\
\text { (Robinson et al. 2014) }\end{array}$ \\
\hline \multirow[t]{18}{*}{ Explanatory factors } & \multirow[t]{4}{*}{ Climatic } & Mean annual temperature & ${ }^{\circ} \mathrm{C}$ & \multirow[t]{4}{*}{ RESDC (http://www.resdc.cn/) } \\
\hline & & Annual Precipitation & $\mathrm{Mm}$ & \\
\hline & & $\begin{array}{l}\geq 10^{\circ} \mathrm{C} \text { Accumulated tempera- } \\
\text { ture }\end{array}$ & ${ }^{\circ} \mathrm{C}$ & \\
\hline & & Moisture index & $\%$ & \\
\hline & \multirow[t]{3}{*}{ Topographic features } & Altitude & $\mathrm{m}$ & \multirow{3}{*}{$\begin{array}{l}\text { NASA SRTM V3.0 } \\
\text { derived from Altitude } \\
\text { RESDC (http://www.resdc.cn/) }\end{array}$} \\
\hline & & Slope & degree & \\
\hline & & Landforms & - & \\
\hline & \multirow[t]{7}{*}{ Soil characteristic } & Sand content & $\%$ & \multirow{7}{*}{$\begin{array}{l}\text { HWSD v1.2 (http://www.fao. } \\
\text { org/soils-portal/soil-survey/ } \\
\text { soil-maps-and-databases/ } \\
\text { harmonized-world-soil-datab } \\
\text { ase-v12/en/) }\end{array}$} \\
\hline & & Silt content & $\%$ & \\
\hline & & Clay content & $\%$ & \\
\hline & & Organic content & $\%$ & \\
\hline & & $\mathrm{pH}$ & $-\log \left(\mathrm{H}^{+}\right)$ & \\
\hline & & Drainage & Class & \\
\hline & & Soil type & - & \\
\hline & \multirow[t]{4}{*}{ Socioeconomic } & Market influence & USD/person & \multirow[t]{2}{*}{ Verburg et al. (2011) } \\
\hline & & Market accessibility & Index $(0-1)$ & \\
\hline & & Population density & People $/ \mathrm{km}^{2}$ & \multirow[t]{2}{*}{ RESDC (http://www.resdc.cn/) } \\
\hline & & GDP & $\mathrm{USD} / \mathrm{km}^{2}$ & \\
\hline \multirow[t]{4}{*}{ Policy } & \multirow[t]{4}{*}{ Future demand } & Crop production & Ton & \multirow{2}{*}{$\begin{array}{l}\text { National planning on medium- } \\
\text { and long-term food security } \\
\text { (National Development and } \\
\text { Reform Commission of China } \\
\text { 2008) }\end{array}$} \\
\hline & & Livestock & Head & \\
\hline & & Built-up area & $\mathrm{km}^{2}$ & $\begin{array}{l}\text { General Land Use Planning in } \\
\text { Hebei Province (2006-2020) } \\
\text { (Hebei Provincial Department } \\
\text { of Land and Resources 2010) }\end{array}$ \\
\hline & & Forest area & $\mathrm{km}^{2}$ & $\begin{array}{l}\text { National Forest Management } \\
\text { Planning (2016-2050) (State } \\
\text { Forestry Administration of } \\
\text { China 2016), Land greening } \\
\text { planning of Hebei Province } \\
\text { (2018-2035) (Hebei Provin- } \\
\text { cial Department of Natural } \\
\text { Resources 2018), Implementa- } \\
\text { tion plan of afforestation in } \\
\text { Zhangjiakou city and Chengde } \\
\text { Bashang area of Hebei Prov- } \\
\text { ince (State Forestry Adminis- } \\
\text { tration of China 2019) }\end{array}$ \\
\hline
\end{tabular}

of the forest, water, built-up land and unused land were firstly delineated using previously processed LULC data. In the LRB, crops are produced by cropland, and livestock (bovines, goats and sheep) are produced by grasslands, therefore the potential cropland production and livestock density were used to classify cropland and grassland systems, respectively. The dataset used for land system delineation is shown in Table 1 . The specific classification 

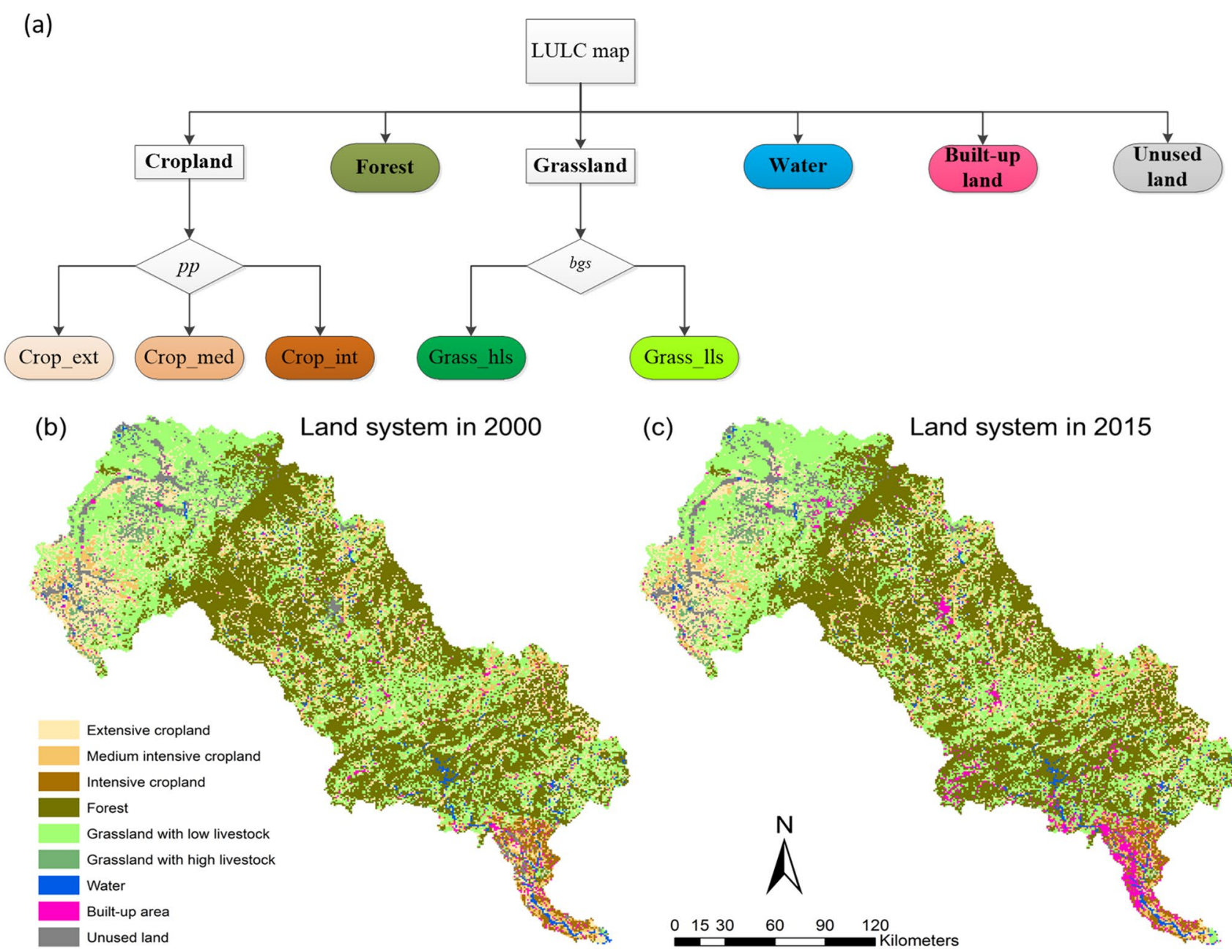

Land system in 2015

Fig. 3 Land system classification approach. The italics represent the classification variables; the boldface represents the main land system categories; and colours represent the final land system classification outcome. Notes: pp is the potential cropland production, bgs is the bovines, goats and sheep density. Crop_ext is extensive cropland $(\mathrm{pp}<0.4)$, Crop_med is medium intensive cropland $(0.4 \leq \mathrm{pp}<0.7)$,

Crop_int is intensive cropland ( $\mathrm{pp} \geq 0.7$ ), Grass_lls is grassland with low livestock (bgs $<100$ ), Grass_hls is grassland with high livestock (bgs $\geq 100$ ). Each variable's classification threshold was arbitrarily determined by the natural breaks in the variable distribution (van Asselen and Verburg 2012)

procedure and delineated land system maps for 2000 and 2015 are illustrated in Fig. 3.

\section{Parameterisation of the CLUMondo Model}

CLUMondo is a forward-looking model that is specifically designed to simulate changes in land cover and changes in land use intensity. Also, it can represent multifunctional land. At the core, the simulation of land use change is based on an empirical analysis of location suitability combined with the dynamic simulation of competition and interactions between the spatial and temporal dynamics of land use systems. The basic principle of the CLUMondo model is to determine the spatial allocation of land systems through ensuring that the allocated land systems fulfil the regional demands for ecosystem goods and services in consideration of the regular supply of these goods and services by the different land systems (Van Asselen and Verburg 2013) (Fig. 4). The CLUMondo model is subdivided into two distinct modules: a non-spatial demand module and a spatially explicit allocation module. The non-spatial module indicates the changes in demand at the level of the entire model region. In this case, demands can refer to the demand for an area of specific land use and a number of goods or services. In the allocation module, these demands are subsequently translated into land use changes at specific locations in the study area, using a raster-based system. In CLUMondo, demands are external input to the system, while the allocation is determined by the model's allocation algorithm, which is supported by the user interface. Land use demands 


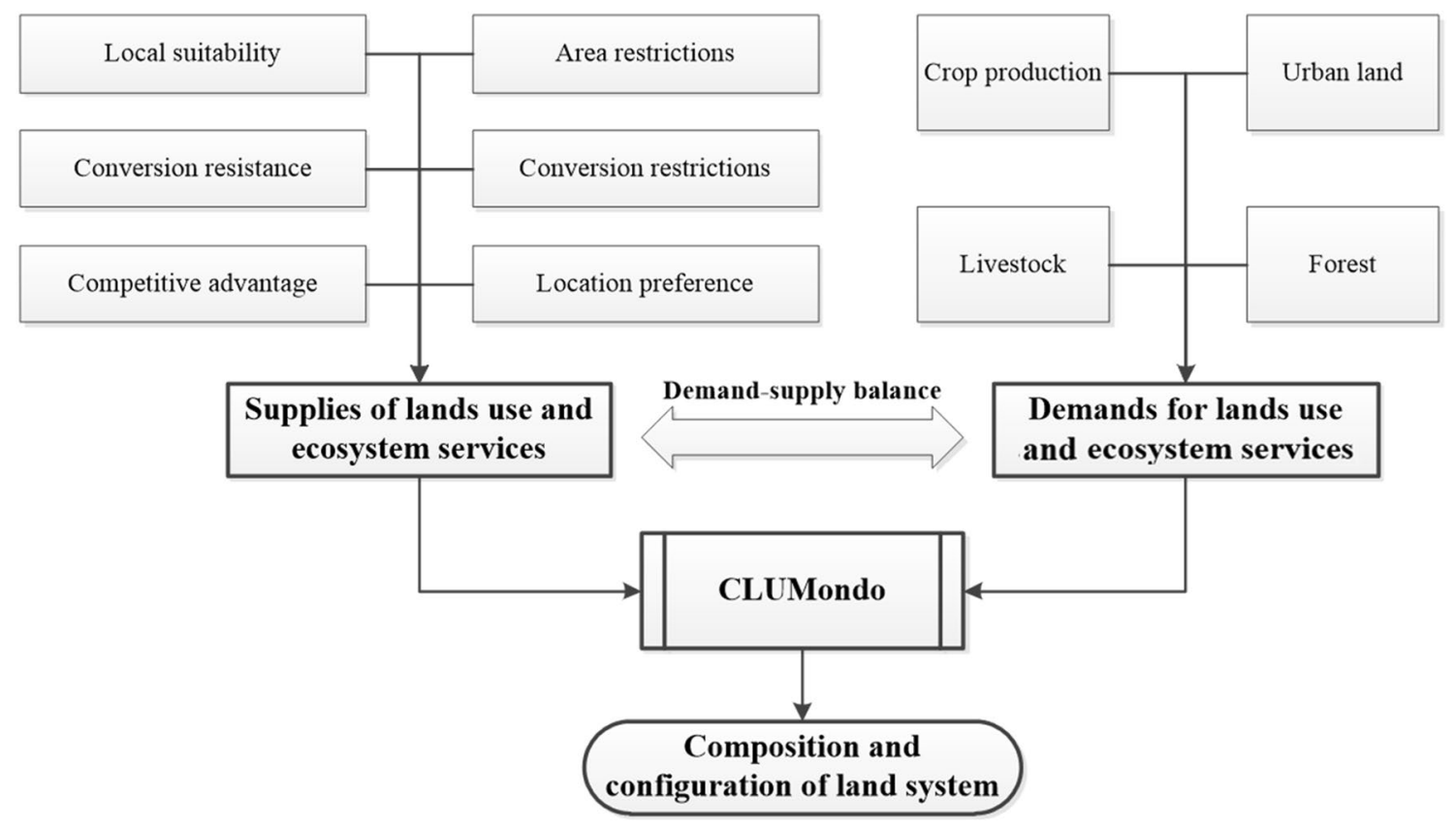

Fig. 4 Main concept and workflow of CLUMondo model (Adapted from Van Asselen and Verburg, 2013)

can be derived in different forms, ranging from simple trend extrapolations to complex economic models. More information about the CLUMondo model and parameter settings can be found in Van Asselen and Verburg (2013).

The demands considered in our study included crop production, livestock, urban land and forest areas. To meet these demands, the land systems are allocated according to their capacity to supply these demands and the local biophysical and socio-economic conditions. To explore the extent to which land systems' spatial determinants can be explained by the independent factors, 18 biophysical and socio-economic factors, including climate, soil properties, topography, and vegetation type, were used (Table 1). Throughout the research period, the driving factors' stability was considered along with the availability, consistency, and quantifiability of the data. Detailed information related to the explanatory factors is also listed in Table 1. To avoid errors caused by data upscaling or downscaling, all data were resampled into a consistent spatial coordinate system (GCS_Krasovsky_1940, Albers Conical Equal Area) and resolution $(1000 \times 1000 \mathrm{~m})$, the same spatial reference as the delineated land systems map. The number of explanatory factors was reduced to 12 after multiple collinearity assessments, wherein any two factors with a correlation coefficient $>0.7$ were excluded. A structured sampling method was then applied to minimise spatial autocorrelation and balance the sample grid, and binominal logistic regressions were performed between the sampled location factors and specific land system (Castella et al. 2007; Ornetsmüller et al. 2016; van Asselen and Verburg 2012). The location factor is shown to calibrate the predicted land use by the information on the area under the curve (AUC), representing the accuracy between 0 and 1 of the calculated regression. Table 2 shows the results of the suitability analysis and the AUC value of each land system. The AUC values for all land systems exceeded 0.69, indicating that selected factors could reasonably explain land systems' spatial distribution.

A land system lookup table indicating the resistance factor, relative order of the land system's contribution to fulfilling a specific demand, and their capacity to supply this demand was developed (see Table 3 ). The resistance factor is one of the land system type-specific settings that determine the temporal dynamics of the simulation, which is related to the reversibility of land use changes. Land system types with high capital investment or irreversible impact on the environment will not easily be converted into other uses as long as there are land requirements for those land systems. The land system with a higher value $(\geq 0)$ has a higher-order for fulfilling the ecosystem services. The crop production provided by cropland systems was calculated based on potential cropland production from the Resources and Environmental Sciences Data Center, Chinese Academy of Sciences (http://www.resdc.cn/), and the livestock number carried by grassland with livestock systems was calculated based on Global Distribution of Livestock (Robinson et al. 2014). Land system requirements of the LRB for supplying the demands between 2000 and 2015 were calculated by extrapolating trends (Kurniawan 2014; Verburg and Veldkamp 2004). Additionally, a conversion matrix was used to indicate which land system conversions were possible. The 


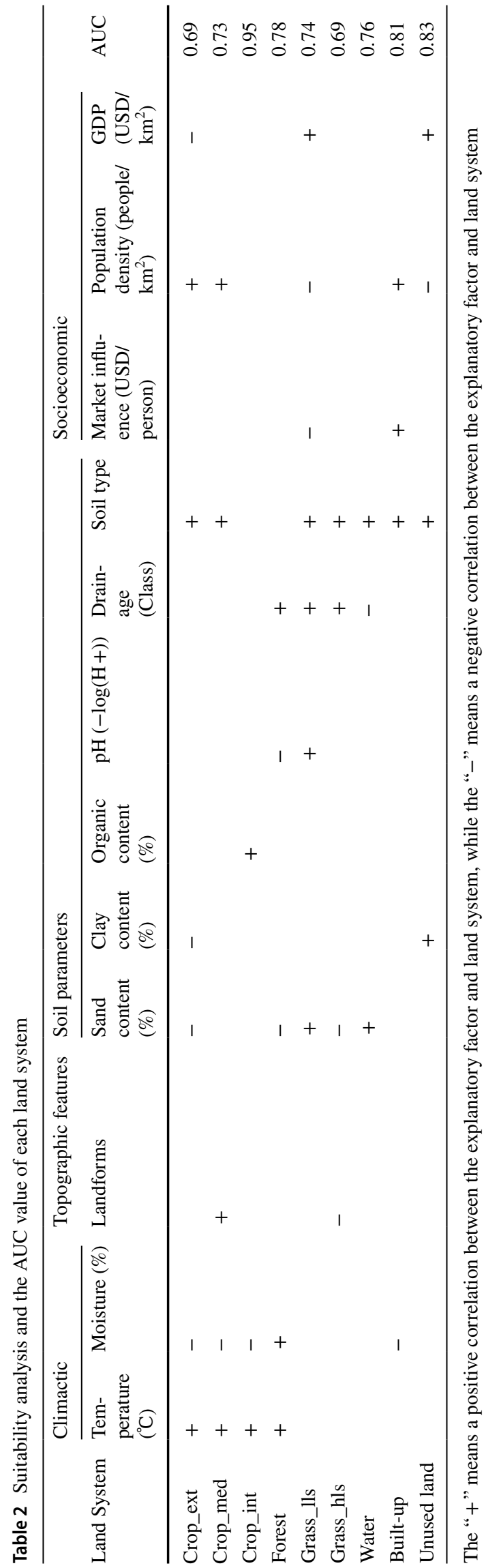

conversion elasticity is derived from referring to previous studies (Jin et al. 2019; Liu et al. 2017; Lu et al. 2009; Park et al. 2011; Zhou et al. 2013) and from repeatedly modifying the calibration of the model to achieve the optimal simulating effect.

\section{Model validation}

Based on the two delineated land system maps, we simulated the land system changes in the LRB from 2000 to 2015 . The model's accuracy was assessed by validating the simulation results using the actual land system map in 2015. Three indicators, including Kappa simulation, Kappa transition, and Kappa transition location, were used to assess the accuracy. Kappa simulation ( -1 to 1 ) is the coefficient of agreement between the simulated land use transitions and the actual land use transitions. Kappa transition (0 to1) expresses the agreement in the quantity of land use transitions, and Kappa transition location ( -1 to 1 ) expresses the degree to which the transitions agree in their allocations. These indices measured the consistency between the simulation results and actual land systems from different aspects, which have been successfully used in evaluating the CLUMondo simulated results (Jin et al. 2019; Liu et al. 2017). Further details regarding calculations and the indices used can be found in van Vliet et al. (2011).

\section{Scenario formulation}

Four scenarios: Trend, Expansion, Sustainability, and Conservation were designed based on different socio-economic development and environmental protection targets, local plans and policies, and the information from a stakeholders' workshop, to explore land system evolution trajectories of the LRB and major challenges that the river basin may face in the future. A stakeholder workshop was held in Tianjin, China, in October 2019 to collate information on the major challenges and their drivers in the basin, local policies, future development plan, and views on ecosystem services in the LRB. 15 stakeholders with extensive theoretical and practical knowledge of the local environment from government bodies, research institutes, and companies participated in the workshop. Full ethical clearance was granted by the University of Glasgow`s research ethics committee for the stakeholder consultation. The study period was selected as 2015-2030 to ensure temporal consistency of different datasets and align with the SDG targets achievement date.

\section{Scenario 1: Trend}

The Trend scenario follows the middle-of-the-road shared socio-economic pathway (SSP2), a pathway of the 
Table 3 The resistance factors and lookup values for each land system

\begin{tabular}{|c|c|c|c|c|c|c|c|c|c|}
\hline \multirow[t]{2}{*}{ Land system } & \multirow{2}{*}{$\begin{array}{l}\text { Resist- } \\
\text { ance } \\
\text { factor }\end{array}$} & \multicolumn{2}{|c|}{$\begin{array}{l}\text { Crop production } \\
\text { (Tons/pixel) }\end{array}$} & \multicolumn{2}{|c|}{$\begin{array}{l}\text { Livestock } \\
\text { (Heads/pixel) }\end{array}$} & \multicolumn{2}{|c|}{$\begin{array}{l}\text { Urban land } \\
\left(\mathrm{km}^{2} / \text { pixel }\right)\end{array}$} & \multicolumn{2}{|c|}{$\begin{array}{l}\text { Forest } \\
\left(\mathrm{km}^{2} / \text { pixel }\right)\end{array}$} \\
\hline & & $\begin{array}{l}\text { Co } \\
\text { sio }\end{array}$ & & & & & & & \\
\hline Crop_ext & 0.6 & 1 & 212.2 & 0 & 0 & 0 & 0 & 0 & 0 \\
\hline Crop_med & 0.7 & 2 & 456.3 & 0 & 0 & 0 & 0 & 0 & 0 \\
\hline Crop_int & 0.8 & 3 & 723.7 & 0 & 0 & 0 & 0 & 0 & 0 \\
\hline Forest & 0.8 & 0 & 0 & 0 & 0 & 0 & 0 & 1 & 1 \\
\hline Grass_1ls & 0.5 & 0 & 0 & 1 & 46.6 & 0 & 0 & 0 & 0 \\
\hline Grass_hls & 0.6 & 0 & 0 & 2 & 124.6 & 0 & 0 & 0 & 0 \\
\hline Water & 0.9 & 0 & 0 & 0 & 0 & 0 & 0 & 0 & 0 \\
\hline Built-up & 0.9 & 0 & 0 & 0 & 0 & 1 & 1 & 0 & 0 \\
\hline Unused land & 0.8 & 0 & 0 & 0 & 0 & 0 & 0 & 0 & 0 \\
\hline
\end{tabular}

The resistance factor is one of the land system type-specific settings that determine the temporal dynamics of the simulation, which is related to the reversibility of land use changes socio-economic trend that does not shift markedly from historical patterns, with relatively low commitment to achieve development goals (O'Neill et al. 2014). In CLUMondo, this scenario is driven by the demand for crop production, livestock, and built-up areas. The average annual change rates of demand for crop production and livestock were calculated using the data from the Statistical yearbook of Hebei Province (2015) (Hebei provincial bureau of statistics 2016). The annual demand for the built-up area was calculated based on land system change between 2000 and 2015. Demands for crop production, livestock number, and built-up space were predicted for the next 15 years using the projected change rates.

\section{Scenario 2: Expansion}

The Expansion scenario follows the fossil-fuelled development shared socio-economic pathway (SSP5), where people exploit abundant fossil fuel resources, the global economy grows at the highest speed, and the global urbanisation rate reaches $92 \%$ in 2100 . The SSP5 scenarios mark the upper end of the scenario literature in fossil fuel use, food demand, energy use and greenhouse gas emissions. The annual change rates for the demand of the built-up area were derived from the future built-up land expansion in China under SSP5 (Chen et al. 2020), and the annual change rates for demands of crop and livestock were derived from the SSP database (https://tntcat.iiasa.ac.at/SspDb).

\section{Scenario 3: Sustainability}

The Sustainability scenario follows the sustainable shared socio-economic pathway (SSP1). The annual demand for crop production and livestock was derived from the projected annual change rates stated in "National planning on mediumand long-term food security" (National Development and Reform Commission of China 2008). The built-up area's annual demand was calculated based on General Land Use Planning in Hebei Province (2006-2020) (Hebei Provincial Department of Land and Resources 2010). It should be noted that the meaning of "Sustainability" used for describing the scenario here is not completely consistent with the concept of sustainability in SDGs. The "Sustainability" scenario follows the "sustainable" shared socio-economic pathway (SSP1), of which the demand for crop production, livestock and build-up area were derived from the relatively sustainable national or regional planning.

\section{Scenario 4: Conservation}

The socio-economic context of the Sustainability scenario was used as a baseline for the Conservation scenario and extended by the implementation of the ecological restoration and protection policy targets. According to the stakeholders and the policy review, a series of policies promoting afforestation have been implemented since 2015 in the Luanhe River Basin for biodiversity conservation and sand fixation. Based on planning data published in the National Forest Management Planning (2016-2050) (State Forestry Administration of China 2016), Land greening planning of Hebei Province (2018-2035) (Hebei Provincial Department of Natural Resources 2018) and Implementation plan of afforestation in Zhangjiakou city and Chengde Bashang area of Hebei Province (State Forestry Administration of China 2019), demands for forest area were linearly interpolated to obtain yearly demand quantities. Demand model parameters related to the four scenarios are described in Table 4 . 
Table 4 Average annual percentage change in demand from 2015 to 2030 for the different scenarios

\begin{tabular}{lllll}
\hline Demand & Trend & Expansion & Sustainability & Conservation \\
\hline Crop production (Ton) & $2.1 \%$ & $1.5 \%$ & $1 \%$ & $1 \%$ \\
Livestock numbers (Head) & $2.7 \%$ & $3.9 \%$ & $0.9 \%$ & $0.9 \%$ \\
Built-up land $\left(\mathrm{km}^{2}\right)$ & $9.6 \%$ & $1.9 \%$ & $0.7 \%$ & $0.7 \%$ \\
Forest $\left(\mathrm{km}^{2}\right)$ & $\mathrm{n} / \mathrm{a}$ & $\mathrm{n} / \mathrm{a}$ & $\mathrm{n} / \mathrm{a}$ & $0.4 \%$ \\
\hline
\end{tabular}

$\mathrm{n} / \mathrm{a}$ refers to the demand which is not specified in the scenario formulation but will be allocated by the CLUMondo model

\section{Terrestrial carbon storage}

The InVEST carbon storage module uses a simplified carbon cycle that quantifies the amount of static carbon storage and dynamic sequestration or loss based on four basic carbon density pools: aboveground biomass (c_above), belowground biomass (c_below), soil (c_soil), and dead organic matter (c_dead) (Sharp et al. 2020). The carbon in each pool was then aggregated over different land use types to estimate carbon storage across the landscape. The carbon storage $S_{m, i, j}$ for a given grid cell $(i, j)$ with land use type $m$ can be calculated as:

$C_{m, i, j}=A \times\left(c_{-}\right.$above $_{m, i, j}+c_{-}$below $_{m, i, j}+c_{-}$soil $_{m, i, j}+c_{\_}$dead $\left._{m, i, j}\right)$,

where $A$ is the actual area of each grid cell (ha) and $c_{\_}$above $_{m, i, j}, c_{\_}$below $w_{m, i, j}, c_{-}$soil $_{m, i, j}$ and $c_{-}$dead $_{m, i, j}$ are the aboveground carbon density $\left(\mathrm{MgC}_{\bullet} \mathrm{ha}^{-1}\right)$, belowground carbon density $\left(\mathrm{MgC} \cdot \mathrm{ha}^{-1}\right)$, soil organic carbon density $\left(\mathrm{MgC} \cdot \mathrm{ha}^{-1}\right)$, and dead organic matter carbon density $\left(\mathrm{MgC} \cdot \mathrm{ha}^{-1}\right)$ for grid cell $(i, j)$ with land use type $m$. Hence, carbon storage $C$ across the whole region can be calculated as:

$\mathrm{C}=\sum_{m=1}^{n} C_{m, i, j}$

Since currently available data of carbon pools are all estimated based on the land use and land cover (LULC) types rather than land system types; in this research, the projected future land system types were regrouped into land use and cover types. The terrestrial carbon storages in the LRB in the baseline and under different future scenarios were calculated based on the carbon storage in cropland (including extensive cropland, medium intensive cropland, and intensive cropland), forest, grassland (including grassland with high livestock and grassland with low livestock), built-up land, and unused land. The four carbon pools in each land use and cover types were collected by a literature review (Table 5). For maximising the carbon pool data gathered from various secondary sources within the study area: (1) we gave priority to the measured data for the LRB. For example, the $c_{-}$above, c_below, c_soil and $c \_d e a d$ in the forest were derived from the measured data of mean carbon densities in the forest of the LRB by Wang and Gao (2009). Most of the grassland in the LRB is located in Inner Mongolia. Therefore, the c_soil in grassland was derived from the measurement data of soil organic carbon density in Inner Mongolia's grassland by Jin et al. (2018); (2) For the carbon pools of which measured data for LRB was not available, we used the measured data for Hebei province. For example, the builtup land and unused land, the $c_{-}$soil wAS derived from the measured data for Hebei province by by Xi et al. (2010); (3) For the rest of the carbon pools, we used the data derived from the national mean carbon densities in China by Tang et al. (2018) and Fang et al. (1996). It should be noted that in the InVEST carbon storage module, the carbon density of each terrestrial pool was assumed not to have changed during the modelling period.
Table 5 Carbon pools of different LULC types in InVEST (units: $\mathrm{MgC} \cdot \mathrm{ha}^{-1}$ )

\begin{tabular}{llllll}
\hline LULC type & c_above & c_below & c_soil & c_dead & Sources \\
\hline Cropland & 2.66 & 0.4 & 92.04 & 0 & Tang et al. (2018) \\
Forest & 27.58 & 4.96 & 157.14 & 8.24 & Wang and Gao (2009) \\
Grassland & 0.43 & 4.4 & 81.2 & 0.08 & Jin et al. (2018); Tang et al. (2018) \\
Built-up land & 0 & 0 & 78 & 0 & Xi et al. (2010) \\
Unused land & 0.1 & 0 & 72.4 & 0 & Fang et al. (1996); Xi et al. (2010)
\end{tabular}

c_above refers to the aboveground biomass. $c_{-}$below refers to the belowground biomass. $c_{-}$soil refers to soil organic carbon. $c \_$dead refers to the dead organic matter 
Table 6 Change in the land system from 2015 to 2030 in the LRB under four different scenarios

\begin{tabular}{|c|c|c|c|c|c|c|c|c|c|}
\hline \multirow[t]{2}{*}{ Land system } & \multirow{2}{*}{$\begin{array}{l}\text { Area percent } \\
\text { in } 2015(\%)\end{array}$} & \multicolumn{4}{|c|}{ Area percent in $2030(\%)$} & \multicolumn{4}{|c|}{ Change area from 2015 to $2030\left(10^{3} \mathrm{~km}^{2}\right)$} \\
\hline & & Trend & Expansion & Sustainability & Conservation & Trend & Expansion & Sustainability & Conservation \\
\hline Extensive cropland & 15.12 & 7.15 & 9.51 & 11.74 & 11.55 & -3.61 & -2.53 & -1.51 & -1.60 \\
\hline $\begin{array}{l}\text { Medium intensive crop- } \\
\text { land }\end{array}$ & 6.50 & 12.92 & 10.87 & 8.70 & 8.78 & 2.95 & 2.01 & 1.01 & 1.05 \\
\hline Intensive cropland & 1.62 & 3.12 & 2.82 & 2.77 & 2.78 & 0.69 & 0.55 & 0.53 & 0.53 \\
\hline Forest & 37.59 & 31.58 & 33.32 & 36.43 & 39.88 & -2.75 & -1.96 & -0.53 & 1.05 \\
\hline $\begin{array}{l}\text { Grassland with low } \\
\text { livestock }\end{array}$ & 29.94 & 28.70 & 28.86 & 32.76 & 28.30 & -0.56 & -0.49 & 1.30 & -0.74 \\
\hline $\begin{array}{l}\text { Grassland with high } \\
\text { livestock }\end{array}$ & 1.14 & 6.61 & 8.76 & 1.82 & 3.48 & 2.51 & 3.49 & 0.31 & 1.07 \\
\hline Water & 1.63 & 1.23 & 1.11 & 1.49 & 1.32 & -0.18 & -0.24 & -0.06 & -0.14 \\
\hline Built-up & 3.44 & 8.67 & 4.57 & 3.91 & 3.91 & 2.34 & 0.46 & 0.16 & 0.16 \\
\hline Unused land & 3.03 & 0.02 & 0.19 & 0.39 & 0.00 & -1.37 & -1.29 & -1.20 & -1.38 \\
\hline
\end{tabular}

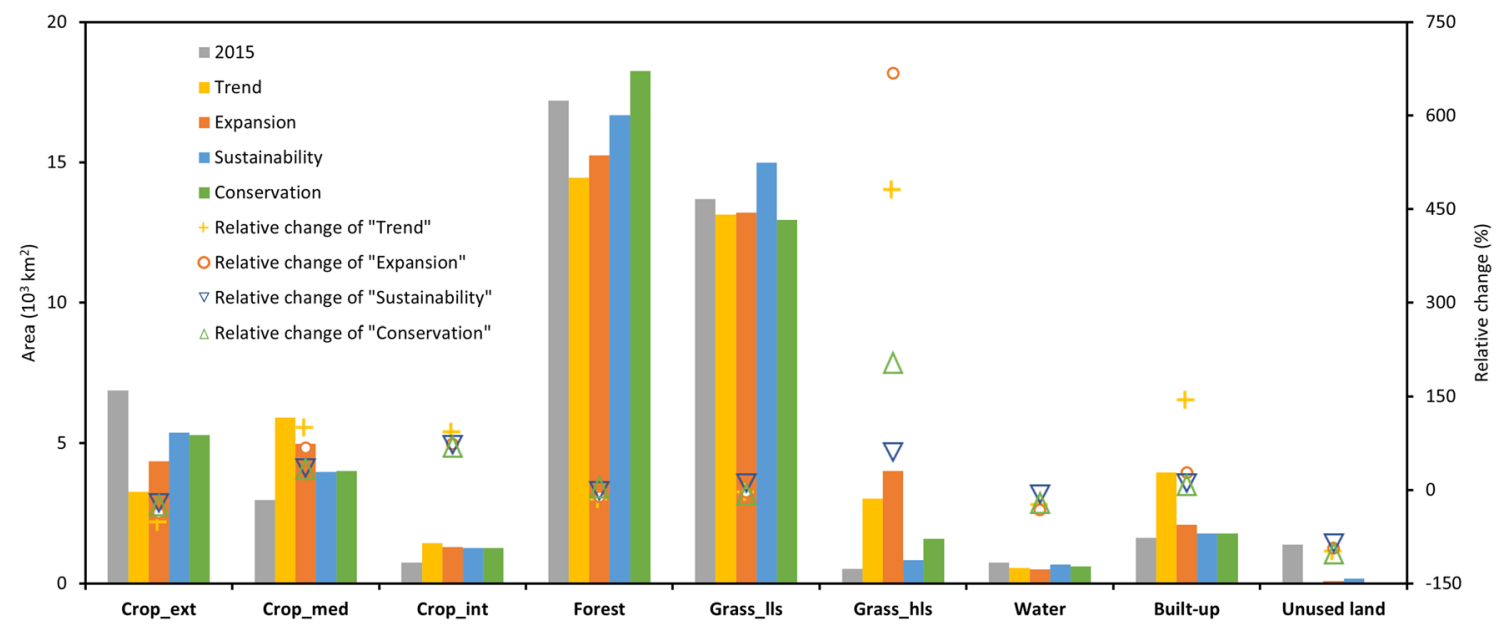

Fig.5 Absolute and relative changes in land system areas in 2015 and predicted values under various scenarios for 2030

\section{Results}

\section{Land system changes from 2015 to 2030 under different scenarios}

The interplay between demands, spatial policies and competition for the nine land system types led to different land system change trajectories from 2015 to 2030 under the Trend, Expansion, Sustainability and Conservation scenarios (Table 6, Tables S1-S4, Figs. 5 and 6). The cropland systems transformed into more intensive versions (Crop_med and Crop_int) in all four scenarios and all predict a decline in extensive cropland. The Trend scenario experienced the highest amount of cropland intensification due to its higher demand for crop production, with a $111 \%$ increase of intensive croplands, a $94 \%$ increase of medium intensive croplands and a 50\% decrease of extensive cropland in the LRB from 2015 to 2030 (Table 6). Although built-up areas accounted for a small portion of the LRB, they exhibited a clear increasing trend in all four scenarios. The forest areas are projected to decrease in the Trend, Expansion, and Sustainability scenarios. Simultaneously, they recorded slight increases in the Conservation scenario because of the forest and biodiversity conservation targets. A considerable portion of the grassland intensification was related to increased demand for livestock. The most significant increase was observed in the Expansion scenario, where large areas of grassland systems with low-density livestock and unused land were replaced by grassland systems with high-density livestock. The Sustainability and Conservation scenarios presented a relatively smaller increase in the grassland systems with high-density livestock compared to the other two scenarios. This can be attributed to sustainable development planning and targets, restricting unreasonable development and 


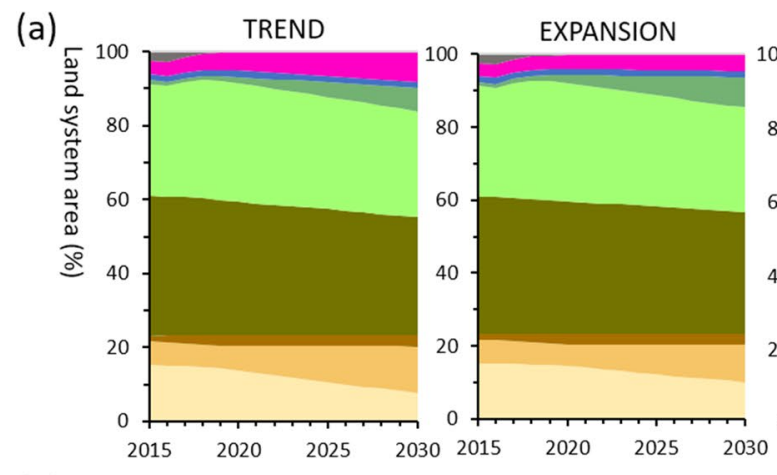

(b)
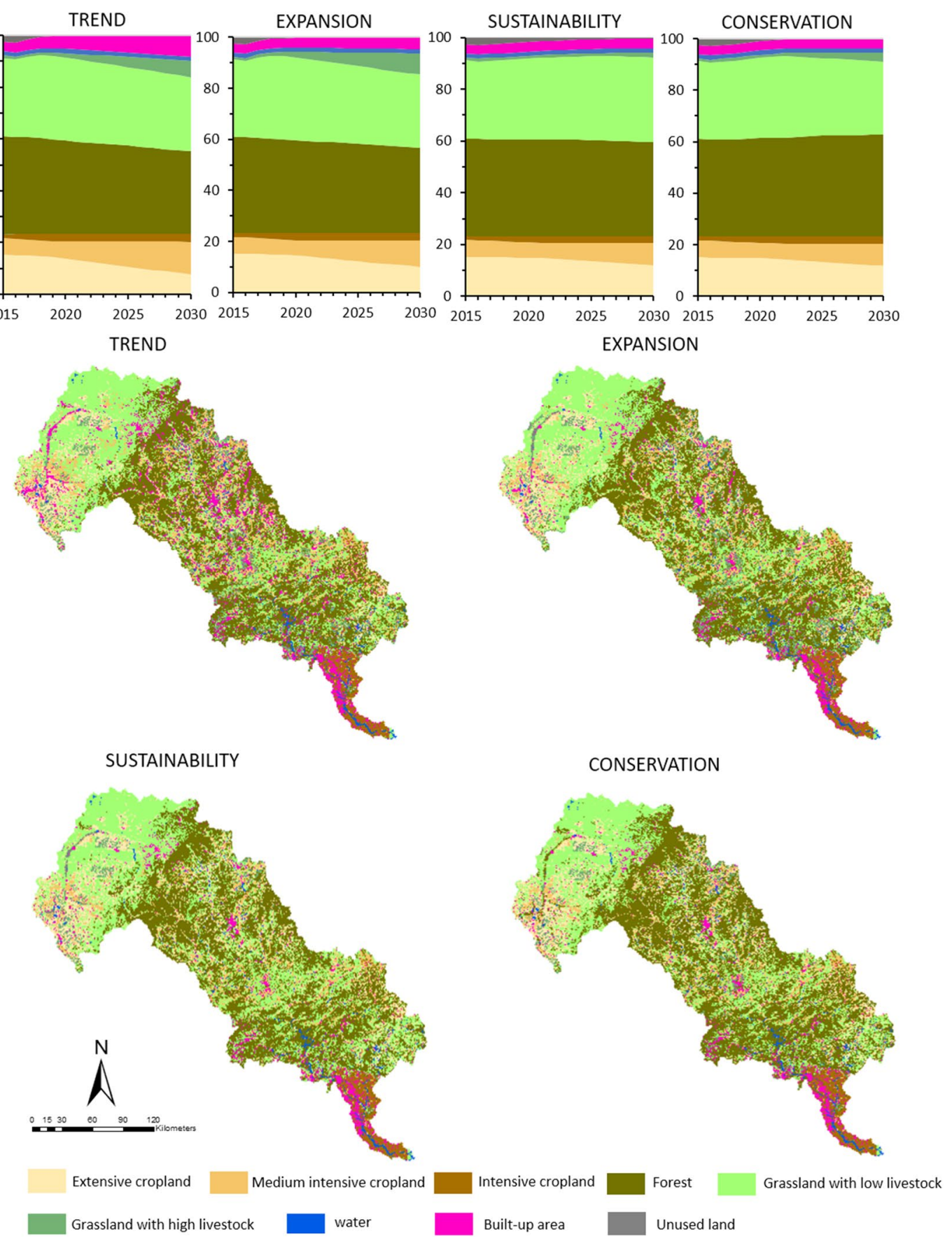

Fig.6 Land system change from 2015 to 2030 in the LRB under different scenarios. (a) percentage of land system area (\%). (b) Land system maps in 2030

unreasonable environmental resources utilisation. The areas of water and unused land were projected to be decreased under all scenarios in 2030. Most of these decreased water areas were projected to be replaced by grassland systems with low-density livestock. The most significant decrease of the unused land area was projected in the Conservation scenario, and most of these decreased unused lands were projected to be explored for forests and grassland systems with low-density livestock.

\section{Simulation of terrestrial carbon storage from 2015 to 2030}

We estimated potential regional carbon storage and change under the four different scenarios from 2015 to 2030 in the LRB (Table 7 and Fig. 7). The largest carbon pool is in the forests, followed by the grasslands, croplands, built-up lands, and unused lands. The results show that unless the 
Table 7 Terrestrial carbon storage $(\mathrm{MtC})$ of the LRB in 2015 and 2030 under four different scenarios

\begin{tabular}{lllllll}
\hline & & 2015 & Trend & Expansion & Sustainability & Conservation \\
\hline Carbon pools & c_above & 50.90 & 43.39 & 45.63 & 49.50 & 53.79 \\
& c_below & 15.22 & 14.71 & 15.57 & 15.66 & 15.88 \\
& c_soil & 506.07 & 487.16 & 494.15 & 503.57 & 516.31 \\
& c_dead & 14.29 & 12.04 & 12.71 & 13.87 & 15.16 \\
LULC types & Cropland & 100.75 & 100.96 & 100.97 & 101.03 & 100.56 \\
& Forest & 340.56 & 286.15 & 301.87 & 330.03 & 361.34 \\
& Grassland & 122.47 & 139.18 & 148.29 & 136.28 & 125.28 \\
& Built-up land & 12.71 & 30.95 & 16.31 & 13.95 & 13.95 \\
Total & Unused land & 9.98 & 0.06 & 0.62 & 1.30 & 0.01 \\
Terrestrial carbon storage change from & $/$ & -29.17 & -18.42 & -3.88 & 14.67 \\
2015 to 2030 & & & & & & \\
\hline
\end{tabular}

biodiversity conservation targets are implemented (Conservation scenarios), carbon storage manifests a decreasing tendency from 2015 to 2030 under all the other three scenarios. However, the carbon losses would significantly reduce under the Sustainability scenario following the sustainable shared socio-economic pathway. The terrestrial carbon storage will decrease by 29.2 MtC, 18.4 MtC and 3.9 MtC under the Trend, Expansion and Sustainability scenarios, and increase by 14.6 MtC under the Conservation scenario. The change of soil carbon storage ( $\left.c \_s o i l\right)$ is the main driver of total terrestrial carbon storage change from 2015 to 2030 , followed by the aboveground carbon pool (c_above).

The loss of carbon stored in the forests is the main driver of the total terrestrial carbon storage loss from 2015 to 2030 in the LRB (Tables S1-S4, and Fig. 8). The carbon storage in the forests is projected to decrease from $340.6 \mathrm{MtC}$ to $286.2 \mathrm{MtC}$ under the Trend scenarios, 301.9 MtC under the Expansion scenarios, and 330.0 MtC under the Sustainability scenarios, which are all far greater than the increased carbon storage due to grassland growth. Under the Trend, Expansion and Sustainability scenarios, the terrestrial carbon storage loss in the LRB will occur due to the extensive forests projected to be replaced by built-up lands, grasslands and croplands (Fig. 7). The conversion from forest to builtup lands will mostly be responsible for terrestrial carbon storage loss under the Trend scenario, while the conversion from forests to the croplands is the main reason for terrestrial carbon storage loss under the Expansion and Sustainability scenarios. Meanwhile, the results from the modelling under Conservation scenario show the implementation of the ecological restoration and protection policy targets would significantly increase the amount of carbon stored in the forests and mildly increase the amount of carbon stored in the grassland, together with leading to the terrestrial carbon storage increase in the LRB (Fig. 8).

\section{Discussion}

\section{Performance evaluation of the model}

Generally, the CLUMondo model has high accuracy with an overall Kappa simulation of 0.86 (Table 8). Kappa transition is close to 1 , indicating its robust ability to simulate the number of land system changes in the LRB. The Kappa transition location value is as high as 0.87 , which indicates that the spatial allocation of these land system changes is much more accurate than random. Kappa values above 0.8 represent strong agreement or accuracy between two maps (Landis and Koch 1977). Therefore, the CLUMondo has good applicability in the LRB and can be used to predict the future simulation of land use change.

Moreover, the Kappa simulation values for all land systems except the built-up land system exceeded 0.77 . The disagreements between the built-up land systems in 2000 and 2015 can be attributed to locational discrepancies with lower Kappa transition location of 0.41 . The area of builtup land only covers $1.47 \%$ of LRB in 2000, but the built-up land represents the largest changed area among all land system types between 2000 and 2015, which increased the area cover to $3.44 \%$ of the LRB in 2015 . Even though, the results showed that the land system changes were simulated with relatively high accuracy compared with the performance of previous similar regional-scale CLUMondo applications (Jin et al. 2019; Liu et al. 2017; van Vliet et al. 2011), of which the Kappa simulation values vary between 0.2 and 0.6 .

\section{Terrestrial carbon storage and land system evolution: implications for the SDGs}

The LRB is the most afforested river basin in North China (Yang et al. 2019). The forest in the LRB is a significant part of China's Three-North Shelter Forest Program, also known as the "Green Great Wall" because its massive area spans 

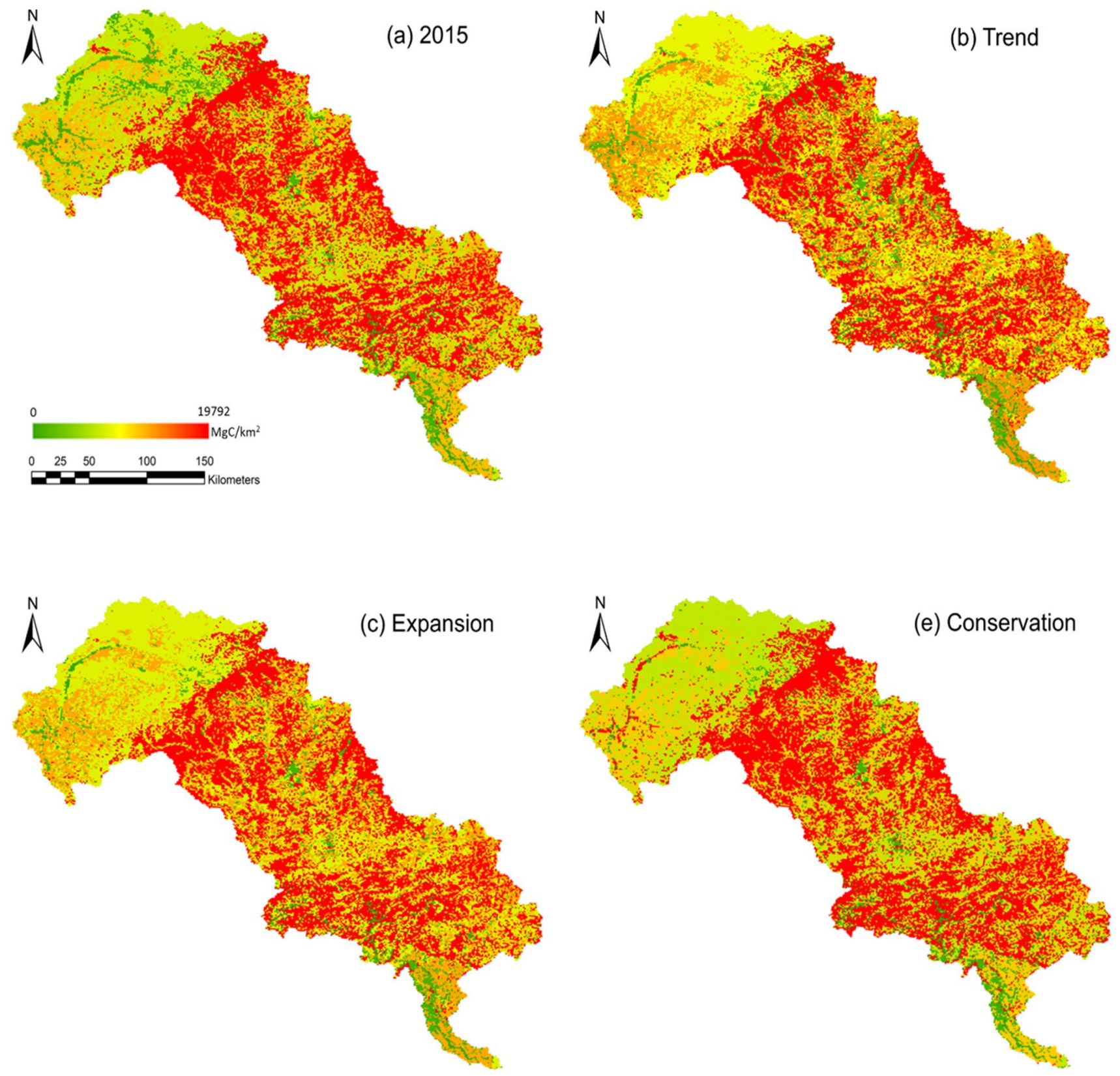

Fig.7 Spatial distribution of terrestrial carbon storage of the LRB in 2015 and 2030 under four different scenarios

half of northern China since the late 1970s. Our simulation demonstrates that the large areas of forests in the LRB continue to be the largest carbon storages in both the vegetation and the soil in the future. The average estimated carbon density in the LRB was $128.1 \mathrm{MgC} \mathrm{ha}^{-1}$ in 2015 , which is 1.2 times China's average of $107.1 \mathrm{MgC} \mathrm{ha}^{-1}$ (Xu et al. 2018a). Therefore, the LRB plays a significant role in storing and capturing carbon and mitigating carbon emissions. However, the simulation results showed that deforestation contributed to forest system change under all scenarios except conservation scenarios, and the loss of carbon stored in the forests is the main driver of the total terrestrial carbon storage loss from 2015 to 2030 in the LRB (Tables S1 to S4, and Fig. 8). Therefore, maintaining and protecting forest ecosystems is critical to mitigating climate change (SDG 13) (Krause and Tilker 2021).

Since 1990, it is estimated that 420 million hectares of forest have been lost globally (FAO and UNEP 2020). Over the past decade, there has been increasing international concern around deforestation and its impact on climate change (Mackey et al. 2015). The United Nations' Sustainable Development Goals (adopted in 2016) aim to fully halt 

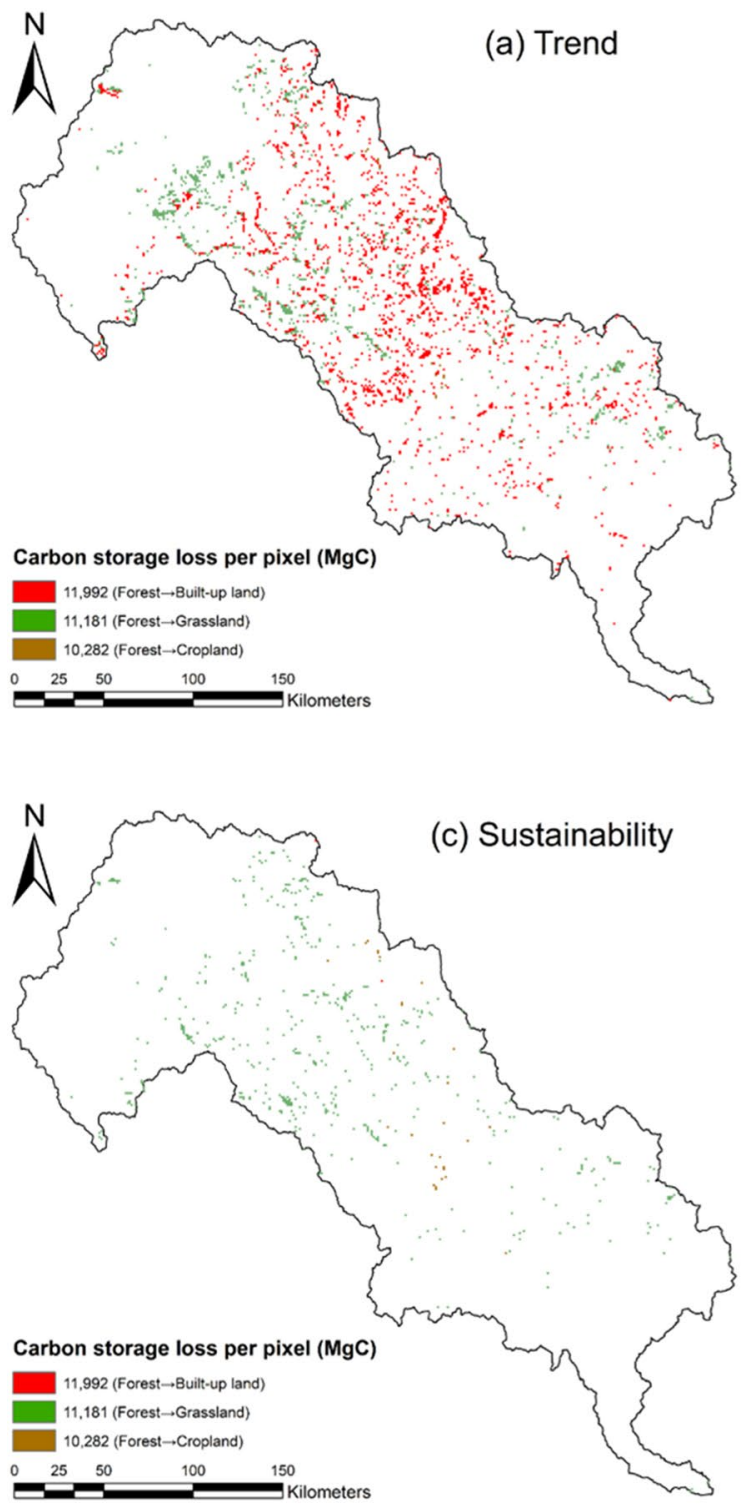

Fig. 8 Terrestrial carbon storage change from 2015 to 2030 under (a) Trend, (b) Expansion, (c) Sustainability and (d) Conservation scenario in the LRB. For each pixel, the forests projected to be replaced by built-up lands would lead to the $11,991 \mathrm{MgC}$ loss, the forests projected to be replaced by grasslands would lead to the $11,181 \mathrm{MgC}$ loss, the forests projected to be replaced by croplands would lead to
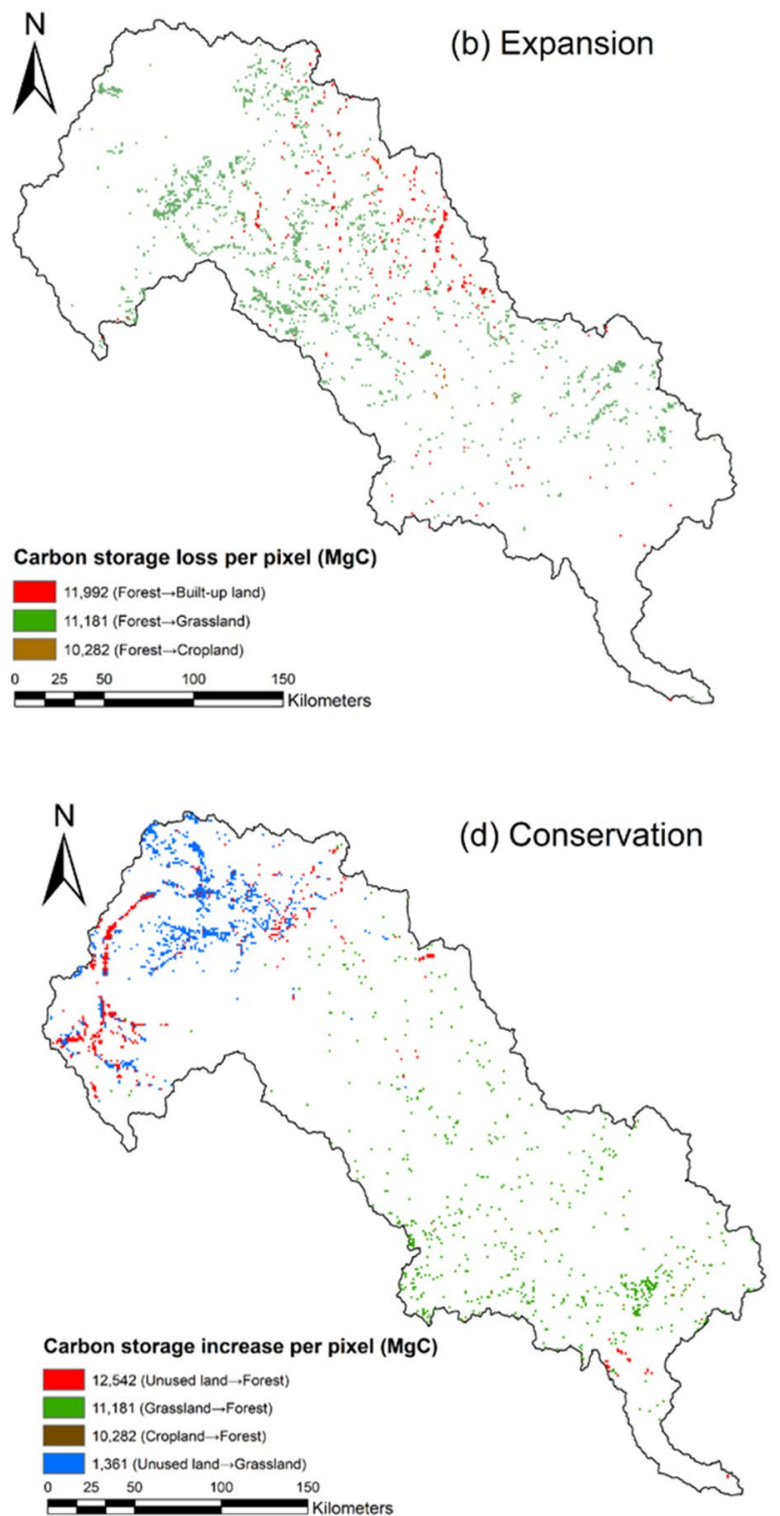

the $10,282 \mathrm{MgC}$ loss, the unused lands projected to be replaced by forests would lead to the $12,542 \mathrm{MgC}$ increase, the grasslands projected to be replaced by forests would lead to the $11,181 \mathrm{MgC}$ increase, the croplands projected to be replaced by forests would lead to the $10,282 \mathrm{MgC}$ increase, the unused lands projected to be replaced by grasslands would lead to the $1361 \mathrm{MgC}$ increase

Table 8 Kappa simulation scores obtained from the assessment of the results of CLUMondo for 2015

\begin{tabular}{lllllllllll}
\hline Accuracy assessment index & Overall & Crop_ext & Crop_med & Crop_int & Forest & Grass_lls & Grass_hls & Water & Built-up & Unused land \\
\hline Kappa simulation & 0.86 & 0.85 & 0.89 & 0.85 & 0.91 & 0.87 & 0.94 & 0.81 & 0.41 & 0.78 \\
Kappa transition location & 0.87 & 0.86 & 0.90 & 0.90 & 0.92 & 0.87 & 0.94 & 0.83 & 0.41 & 0.85 \\
Kappa transition & 0.99 & 0.99 & 0.99 & 0.94 & 0.99 & 0.99 & 0.99 & 0.97 & 0.99 & 0.91 \\
\hline
\end{tabular}


deforestation (UNDP 2015). Therefore, it is essential to take urgent action to combat climate change and its impacts by afforestation and sustainable forests management. As the LRB is the most afforested river basin in north China, it is particularly effective and efficient for the government to promote sustainable forest management, including climate change mitigation in the forest sector, by linking different policy measures. Such activities would provide co-benefits for both climate change mitigation (through increased carbon stocks) and adaptation by increasing ecosystems' resilience to climate-related hazards and related disasters. Since 2015 , a series of policies promoting afforestation have been implemented in the LRB, including; 'National Forest Management Planning (2016-2050)' (State Forestry Administration of China 2016), 'Land greening planning of Hebei Province (2018-2035)' (Hebei Provincial Department of Natural Resources 2018), and 'Implementation plan of afforestation in Zhangjiakou city and Chengde Bashang area of Hebei Province' (State Forestry Administration of China 2019). Such policies are encouraging from the perspective of climate change mitigation (SDG13), and could contribute to the formulation of more ambitious sustainable forest management policies that can be considered in the future.

In our simulations, most deforestation is projected to occur around urban areas and where grassland and cropland systems replace the forests. Therefore, in addition to forest protection, it would be possible to compensate for the carbon loss due to deforestation by increasing the carbon storage in the grassland and cropland systems and decreasing the carbon emission due to grazing and agricultural activities. Climate-smart agriculture (CSA) has been promoted as a systematic approach for developing agricultural strategies to ensure sustainable food security in the context of mitigation practices, promoting carbon sequestration from the atmosphere (Lipper et al. 2014; Palombi and Sessa 2013). In addition to advancing climate (SDG 13) and food security (SDG 2), when a CSA approach is well designed, it can also contribute to urban development (SDG11) and life on land (SDG 15) (FAO 2019). In the North China Plain, the CSA practices have been demonstrated to decrease the food carbon footprint and increase nitrogen use efficiency and irrigation water-use efficiency since 2000 (Xin and Tao 2021). Considering the topographical characteristics and meteorological environment of the LRB, the management practices of adding cover crops into the crop rotation (Kaye and Quemada 2017), applying biochar to soils (Hou et al. 2020), and minimising soil tillage (i.e. conservation tillage) (Zhen et al. 2020) could be promoted and incorporated into regional plans.

All scenarios indicate that the LRB is likely to face both land cover change and land use intensification in socioeconomic development and environmental conservation between 2015 and 2030, while the change trajectories varied greatly under different scenarios in various parts of the LRB (Fig. S1). The southern, north-western and middle parts of the LRB are characterised by low topographic relief, intensive human activity, and mixed cropland and urban systems. China has set urbanisation as one of the core development strategies for economic growth and social development in its recent Five-Year plans (Cui et al. 2019). In the LRB, expanding the built-up system is projected to be around the original urban areas, expanding into the surrounding areas under all four future scenarios. Particularly, in the Trend and Expansion scenarios, extensive unused land near the urban areas would be utilised for built-up areas. However, not all of these urban expansions under future scenarios will lead to the strengthening of the sustainable planning and management of urbanisation in China, in the context of SDG 11 (sustainable cities and human settlements). Rapid urbanisation exerts pressure on food and fresh water supplies, the living environment, and public health. The conservation activities such as afforestation under the Conservation scenario would benefit the achievement of SDG 13 (climate change), although it could hinder the local economic development. Such comprehensive trade-offs and synergies between different SDGs under all future scenarios have been analysed based on the SDG Interlinkages Tool (Zhou et al. 2017) and showcased for the LRB by Zhou et al. (2021; submitted manuscript in this special feature). In this study, we will discuss the selected SDGs, which are most relevant to the LRB.

The demand for crop and livestock is expected to increase in the future (SDG 2). However, the cropland (i.e. crop_ext, crop_med, and crop_int) and grassland (i.e. grass_lls and grass_hls) cover is rather limited in the LRB. The traditional extensive farming pattern was replaced by cropland systems mainly through intensification due to the crop demand for rapid urbanisation in the LRB. The high demand for livestock in the future will result in the intensification of grazing activities in the grassland. The results show that the intensification is projected to be the main source of future grassland system change, widely distributed in the upper stream of LRB. As agriculture is the greatest water-use sector in China (Li et al. 2021), this projected agricultural intensification would be crucial to water scarcity (SDG 6) in the LRB. The future forests area in the LRB would also be relevant to future water quantity and quality (SDG 6), climate change (SDG 13), and life on land (SDG 15). Hence, it is of interest and necessity to discuss the interlinkages of SDG 2 (zero hunger), SDG 6 (water), SDG11 (sustainable cities), SDG 13 (climate change) and SDG 15 (life on land) in the context of LRB's land system evolution under future scenarios at the sub-national scale. 


\section{Trade-offs and synergies between SDG 2 (zero hunger), SDG 6 (water), SDG11 (sustainable cities), SDG 13 (climate change) and SDG 15 (life on land)}

Globally, human water security, the health of aquatic environments and river biodiversity have been greatly impacted by climate change and human socio-economic development over the past few decades (Jacobsen et al. 2012; van Vliet et al. 2013; Vörösmarty et al. 2010). Water scarcity is an imbalance of water supply and demand. It refers to the relative shortage of water in a water supply system which can be affected by the supply, demand and quality of water in a river basin due to climate change or human actions (Liu et al. 2016; Pereira et al. 2009). The SDGs aim to address these issues, focusing on water and sanitation in SDG 6 and related targets in many other goals. The BTH region is the most severely region in China affected by water scarcity (Li et al. 2017a). Although the new South-to-North Water Transfer Project (Zhang 2009) could mitigate part of the water scarcity issue in the BTH, the LRB currently still plays an important water supply function for Tianjin city, a key metropolis of the BTH. The land system changes under future scenarios in the LRB indicate the challenge to achieve the SDG target 6.1 (drinking water for all), target 6.3 (water quality), target 6.4 (address water scarcity), and SDG11 (sustainable cities) in the sub-national regions such as BTH.

Water scarcity in the LRB is likely to increase in the near future. On the one hand, providing sufficient food, increasing productivity and production (SDG target 2.1 and 2.4), and substantially increasing the number of cities and human settlements (SDG target 11.b) will lead to an increase in the water demand in the LRB due to the growth of human population, crop cultivation and grazing, and rapidly changing diets, including greater consumption of animal source foods (Harris et al. 2020; Lehner et al. 2006; Rosegrant et al. 2009). However, due to rainfall reduction, land use change and construction of many small check dams for soil and water conservation, the average annual runoff had decreased by approximately $30 \%$ since the 1980s (Ping et al. 2008). By 2040, the sustainable water supply in Haihe River Basin (containing the LRB) will be more challenging due to the warmer and drier climate and more intense extreme weather events (Chu et al. 2010).

On the other hand, nonpoint-source pollution due to anthropogenic activities such as LULC is the main factor affecting surface water quality (Charalampous et al. 2015; Rong et al. 2009; Zhou et al. 2014), impacting upon the achievement of target 6.3 (water quality). All future scenarios indicate a significant increase in intensively managed cropland and grassland systems in the LRB. However, the intensive cropping practices (e.g. mechanisation) and improved nutrient management (e.g. high agrochemical inputs) for increasing crop and grass yield frequently will result in negative impacts on water quality, including runoff of sediments and agrochemicals to surface waters, as well as biodiversity loss and reductions in cultural services (Benayas and Bullock 2012; Ju et al. 2007; Tsiafouli et al. 2015). Also, the change of climatic conditions in the future may lead to some uncertainties in water environment quality improvement, risk prevention and control effectiveness (Michalak 2016). In particular, the projected increased intensity and frequency of extreme weather events in the LRB will increase the possibility of pollution incidents and make water environment risk prevention more difficult in the future. Overall, the results show that the LRB will suffer more from both quantity- and quality-induced water scarcity problems in the future, it is therefore of importance to address the changes in water scarcity under the effect of rapid urbanisation. Special attention to environmental management and sustainable land system design must be directed towards reducing water pollution and encouraging water conservation for minimising the trade-off between SDG 2 (zero hunger), SDG 6 (water), SDG 11 (sustainable cities), and maximising their synergies.

Due to forests' capacity to store and capture carbon (Katila et al. 2017; Popkin 2019; Seymour and Busch 2016), improve air quality (Eisenman et al. 2019; Nowak et al. 2006), soil and water conservation (Biao et al. 2010; Zhu et al. 2018) and maintain biodiversity (Sayer et al. 2019), forests dynamics and how human societies interact with forests have been associated with SDG 6 (water), SDG11 (sustainable cities), SDG 13 (climate change) and SDG 15 (life on land), and play a significant role in ecosystem services (Xu et al. 2021; submitted manuscript in this special feature) in the LRB. However, unsustainable urban expansion (i.e. Trend and Expansion scenarios) will significantly reduce carbon storage (SDG 13; Table 8), by replacing a large number of forests with built-up lands (SDG target 11.b), croplands and grasslands (SDG target 2.1 and 2.4) (Fig. 8). Such deforestation due to unsustainable urban expansion will also hinder the achievement of SDG target 6.3 (water quality), target 11.6 (air quality), and several targets of SDG 15 (i.e. targets 15.1, 15.2, 15.4, 15.5, 15.8). Compared with the economic expansion-oriented development plan, the sustainable shared socio-economic pathway (Sustainability scenario) and conservation practices (Conservation scenario) are likely to increase carbon uptake in the LRB's terrestrial ecosystems and compensate for the carbon loss due to the socio-economic development and population growth in the future. Therefore, implementing future ecological restoration projects and protection policies could be an important strategy for maximising the synergy of SDGs 6,11 , 13, 15. However, under the Conservation scenario, several grassland systems with low-density livestock and extensive cropland systems with low crop production potential convert to forest in the northwest part of the LRB. In this 
case, the implementation of afforestation could hinder the achievement of SDG 2, though this may not necessarily be so, since the agricultural intensification and the CSA mentioned above could also achieve growth of food production.

\section{Limitations}

In this study, even though, the results showed that the land system changes were simulated with relatively high accuracy compared with the performance of previous similar regionalscale CLUMondo applications (Jin et al. 2019; Liu et al. 2017; van Vliet et al. 2011), the generalisation performance of the prediction was not high for land systems with less area (e.g. built-up land) during the training period (2010-2015). This could lead to the underestimation or overestimation of the land system changes in the LRB to some extent. In addition, in the CLUMondo, all demands (i.e. crop production, livestock, urban land and forest areas) were assumed to maintain a steady annual percentage change, and agriculture production efficiency (i.e. crop and livestock) on different land systems were assumed unchanged from 2015 to 2030. In reality, changing environmental conditions, constraints on different land systems, and consumer behaviour will impact the region's trade balance and demand. Future climate change's uncertainty and agricultural advancements will also affect future agricultural production and agriculture productions' efficiency on different land systems.

It is often difficult to get consensus for designing the local scenario in a stakeholder meeting. There is a universal limitation for this approach in that the attitude of each individual stakeholder towards the future is undeniably dependent on a stakeholder' own knowledge, the experience of the surrounding environment, as well as the stakeholder' implicit assumptions about the future (Hewitt et al. 2014; Milestad et al. 2014; Patel et al. 2007). For, minimising this discordance, we used the focus group discussion approach to summarise the stakeholders' ideas in the stakeholder meeting, and to finalise the scenarios which are scientifically sound and most acceptable for the stakeholders based on the integrated methodology considering the different socio-economic development and environmental protection targets, local plans and policies, and the information shared from the stakeholders' workshop.

Another limitation is due to the uncertainty and emerging knowledge after the scenarios for this study were developed. China recently announced the climate goal to achieve carbon neutrality before 2060, the rapid introduction of renewable energy for decarbonisation and potential for social-technological innovations for the carbon neutrality target could also impact future land systems change (Bowyer and Kretschmer 2010; Poggi et al. 2018; van de Ven et al. 2021; Xiao et al. 2021), and the achievement of SDGs, such as SDG 9: Industry, innovation, and infrastructure and SDG 17: Partnership for the goals (Hinson et al. 2019; Sinha et al. 2020; Walsh et al. 2020). Nevertheless, these effects have not been fully considered by the SSP scenarios used in this study. This study only simulates the future land use change until 2030 to align with the SDG targets achievement date, but future research could generate new knowledge and the an amended SSP for China or even the LRB to better understand the prospective role of land use in achieving the SDGs and contributing to a carbon-neutral China by 2060 .

Furthermore, the COVID-19 pandemic will also impact the development of pathways from different scenarios. The COVID-19 pandemic has brought an unprecedented threat to public health in all countries and the global economy. Although the sustainable recovery from COVID-19 in China should be taken into account in China's 14th Five-Year Plan (Ahmad et al. 2020), COVID-19 could threaten the achievement of some of the SDGs, such as SDG 6: access to water and sanitation (The Lancet Public 2020), and SDG 2: food security (Laborde et al. 2020). Therefore, the scenarios presented should be seen as experiments of what is feasible in terms of meeting such demands (i.e. crop production, livestock, urban land and forest areas) under various constraints.

It should be noted that the methodology of the InVEST carbon model relies on the differences in carbon densities between LULC types. In this study, we have used the available data of carbon pools that fit with the study area to the greatest extent possible. However, for some carbon pools where measured data for the LRB or Hebei province are not available, we used data derived from the national mean carbon densities in China. We believe this would only have a negligible impact on the total terrestrial carbon storage of the LRB since the carbon pools of forest and grassland derived from the in situ-measured data account for the overwhelming majority (more than $75 \%$ ) of terrestrial carbon storage of the LRB. In future studies, additional in situ-measured carbon pool data would be helpful for modelling the carbon storage more reliably. Besides, the InVEST assumes that none of the LULC types in the landscape is gaining or losing carbon over time. The use of average inventory values for carbon fails to account for variation within a LULC type due to many factors, including land management history, temperature or elevation (Chaplin-Kramer et al. 2015). However, the carbon densities in biomass and soil can be influenced by many factors and will change during the modelling period. For example, the change of tillage practices and land management on cropland in the future will impact the soil organic carbon stability and density of cropland (Di et al. 2017; Luo et al. 2019; Zhao et al. 2015). Also, the carbon density of biomass in forests should increase over time, which means the carbon loss due to the future deforestation of aged trees will be significantly larger than the afforestation-leading carbon gain in the biomass (Fang et al. 2007, 2014). Another limitation is the carbon dynamic from 
one pool to another is not captured in the model. For example, if trees in a forest die due to disease, much of the carbon stored in aboveground biomass becomes carbon stored in other (dead) organic material. Even so, due to a lack of appropriate process-based models, this space for time substitution models which do not require site-specific calibration, such as InVEST is currently necessary (Sharps et al. 2017).

\section{Conclusions}

Through the use of land system modelling, we investigated some potential trade-offs and synergies between different SDGs under different socio-economic and environmental targets. LULC change is closely related to the sustainable development of a region and local planning and policy. The land systems in the LRB are not only essential elements of any strategy to stabilise our climate (e.g. forests for SDG 13: climate action) as the natural means of carbon capture and storage, but also they are playing important roles in food provisioning (e.g. cropland and grassland for SDG 2: zero hunger), water security (SDG 6: water and sanitation), urbanisation (SDG11: sustainable cities), and biological diversity (SDG 15: life on land). Therefore, the LRB presents an optimum case for analysing SDGs' trade-offs and synergies at the sub-national scale.

In this study, the land system approach, which provides comprehensive information on socio-ecological factors, was used to explore the potential land system changes of the LRB by 2030 . Four scenarios, which considered multiple demands for commodities and services, representing different pathways of managing LRB's land resources, were simulated using the CLUMondo model. The simulated land use maps are freely available from NERC Environmental Information Data Centre (https://doi.org/10.5285/a94640dcfe21-4c38-936b-d62dfca0c952). The intensification of land systems has been acknowledged as a significant adaptation to population growth (Butsic and Kuemmerle 2015; Kuemmerle et al. 2013). All future scenarios indicate a significant increase in intensively managed cropland and grassland systems (SDG 2) and urban growth (SDG 11) in the LRB, leading to increased water scarcity (SDG 6). The unused land needs to be exploited to meet the increased demand for livestock, cropland, urban area and forest in different scenarios. Apart from the Conservation scenario, the forest areas (SDG 15) are projected to decrease under three scenarios by 2030, resulting in decreased carbon storage (SDG 13 ) in the LRB. To minimise the trade-offs and maximise the synergies between urbanisation and environmental and biodiversity conservation, the posed additional challenges to the region's scarcer land is unavoidable (Eitelberg et al. 2016; Van Asselen and Verburg 2013). The LRB needs policy coherence and synergies, with the integrated thinking of placing the nexus at the centre in meeting the sustainable demands across the water, energy, food, and biodiversity sectors. The LRB needs to embrace greater participation and transparency to optimise important policy gains in effectiveness.

Our findings will help understand future land use patterns under various social demands in the LRB but could have important development implications beyond the LRB. Potential trade-offs between economic development and environment protection exist in many sub-national scale large river basins in China and beyond. Our findings can guide regional sustainable development and rational utilisation of land resources in other sub-national scale river basins in China, and will be valuable for policy and planning purposes to the pursuance of SDGs at the whole national scale. Furthermore, the results can be used in further modelling of SDG synergies and trade-offs, for example, the results from this study were used to provide quantitative and qualitative information to the SDG interlinkages tool (https://sdginterli nkages.iges.jp/luanhe/index.html) (Zhou et al. 2021; submitted manuscript in this special feature).

Supplementary Information The online version contains supplementary material available at https://doi.org/10.1007/s11625-021-01004-y.

Acknowledgements We acknowledge funding from the UK Research and Innovation (UKRI) through the Natural Environment Research Council's (NERC) Towards a Sustainable Earth (TaSE) programme, for the project "River basins as 'living laboratories' for achieving sustainable development goals across national and sub-national scales" (Grant no. NE/S012427/1) on which this research is based. We thank Suiliang Huang from Nankai University, Qiuhua Liang, Lee Bosher, Xilin Xia, and Jiaheng Zhao from Loughborough University, Trevor Hoey from Brunel University, Xin Zhou and Mustafa Moinuddin from the Institute for Global Environmental Strategies for their contributions to the stakeholders workshop and comments and suggestions throughout the project. We also thank all the stakeholders who participated in this study. We are grateful to two anonymous reviewers and the editor for their constructive comments.

Open Access This article is licensed under a Creative Commons Attribution 4.0 International License, which permits use, sharing, adaptation, distribution and reproduction in any medium or format, as long as you give appropriate credit to the original author(s) and the source, provide a link to the Creative Commons licence, and indicate if changes were made. The images or other third party material in this article are included in the article's Creative Commons licence, unless indicated otherwise in a credit line to the material. If material is not included in the article's Creative Commons licence and your intended use is not permitted by statutory regulation or exceeds the permitted use, you will need to obtain permission directly from the copyright holder. To view a copy of this licence, visit http://creativecommons.org/licenses/by/4.0/.

\section{References}

Ahmad E, Stern N, Xie C (2020) From rescue to recovery: towards a sustainable transition for China after the COVID-19 pandemic. 
London: Grantham Research Institute on Climate Change and the Environment and Centre for Climate Change Economics and Policy, London School of Economics and Political Science

Alcamo J, Schaldach R (2006) LandShift: global modelling to assess land use change. In: Tochtermann K, Scharl A (eds) Managing environmental knowledge. Shaker Verlag, Aachen, pp 223-230

Barnaud C, Corbera E, Muradian R, Salliou N, Sirami C, Vialatte A, Choisis J-P, Dendoncker N, Mathevet R, Moreau C (2018) Ecosystem services, social interdependencies, and collective action. Ecol Soc 23(1):1-14

Benayas JMR, Bullock JM (2012) Restoration of biodiversity and ecosystem services on agricultural land. Ecosystems 15(6):883-899

Bi W, Weng B, Yuan Z, Ye M, Zhang C, Zhao Y, Yan D, Xu T (2018) Evolution characteristics of surface water quality due to climate change and LUCC under scenario simulations: a case study in the Luanhe River Basin. Int J Environ Res Public Health 15(8):1724

Biao Z, Wenhua L, Gaodi X, Yu X (2010) Water conservation of forest ecosystem in Beijing and its value. Ecol Econ 69(7):1416-1426

Bowen KJ, Cradock-Henry NA, Koch F, Patterson J, Häyhä T, Vogt J, Barbi F (2017) Implementing the "Sustainable Development Goals": towards addressing three key governance challengescollective action, trade-offs, and accountability. Curr Opin Environ Sust 26:90-96

Bowyer C, Kretschmer B (2010) Anticipated indirect land use change associated with expanded use of biofuels and bioliquids in the EU-an analysis of the national renewable energy action plans. Institute for European Environmental Policy, p 24

Butsic V, Kuemmerle T (2015) Using optimization methods to align food production and biodiversity conservation beyond land sharing and land sparing. Ecol Appl 25(3):589-595

Calvin K, Bond-Lamberty B, Clarke L, Edmonds J, Eom J, Hartin C, Kim S, Kyle P, Link R, Moss R (2017) The SSP4: a world of deepening inequality. Glob Environ Chang 42:284-296

Castella JC, Kam SP, Quang DD, Verburg PH, Hoanh CT (2007) Combining top-down and bottom-up modelling approaches of land use/cover change to support public policies: application to sustainable management of natural resources in northern Vietnam. Land Use Policy 24(3):531-545

Chaplin-Kramer R, Sharp RP, Mandle L, Sim S, Johnson J, Butnar I, Canals LMi, Eichelberger BA, Ramler I, Mueller C (2015) Spatial patterns of agricultural expansion determine impacts on biodiversity and carbon storage. Proc Natl Acad Sci 112(24):7402-7407

Charalampous N, Kindou A, Vlastos D, Tsarpali V, Antonopoulou M, Konstantinou I, Dailianis S (2015) A multidisciplinary assessment of river surface water quality in areas heavily influenced by human activities. Arch Environ Contam Toxicol 69(2):208-222

Chen G, Li X, Liu X, Chen Y, Liang X, Leng J, Xu X, Liao W, Wu Q, Huang K (2020) Global projections of future urban land expansion under shared socioeconomic pathways. Nat Commun 11(1):1-12

Chu J, Xia J, Xu C, Singh V (2010) Statistical downscaling of daily mean temperature, pan evaporation and precipitation for climate change scenarios in Haihe River, China. Theoret Appl Climatol 99(1-2):149-161

Costanza R, De Groot R, Sutton P, Van der Ploeg S, Anderson SJ, Kubiszewski I, Farber S, Turner RK (2014) Changes in the global value of ecosystem services. Glob Environ Chang 26:152-158

Cui Y, Liu J, Xu X, Dong J, Li N, Fu Y, Lu S, Xia H, Si B, Xiao X (2019) Accelerating cities in an unsustainable landscape: Urban expansion and cropland occupation in China, 1990-2030. Sustainability 11(8):2283

DeFries R, Rosenzweig C (2010) Toward a whole-landscape approach for sustainable land use in the tropics. Proc Natl Acad Sci 107(46):19627-19632
Di J, Feng W, Zhang W, Cai A, Xu M (2017) Soil organic carbon saturation deficit under primary agricultural managements across major croplands in China. Ecosyst Health Sustain 3(7):1364047

Ebi KL, Hallegatte S, Kram T, Arnell NW, Carter TR, Edmonds J, Kriegler E, Mathur R, O’Neill BC, Riahi K (2014) A new scenario framework for climate change research: background, process, and future directions. Clim Change 122(3):363-372

Eisenman TS, Churkina G, Jariwala SP, Kumar P, Lovasi GS, Pataki DE, Weinberger KR, Whitlow TH (2019) Urban trees, air quality, and asthma: an interdisciplinary review. Landsc Urban Plan 187:47-59

Eitelberg DA, van Vliet J, Doelman JC, Stehfest E, Verburg PH (2016) Demand for biodiversity protection and carbon storage as drivers of global land change scenarios. Glob Environ Chang 40:101-111

Ellis EC, Klein Goldewijk K, Siebert S, Lightman D, Ramankutty N (2010) Anthropogenic transformation of the biomes, 1700 to 2000. Glob Ecol Biogeogr 19(5):589-606

Ermolieva TY, Ermoliev YM, Havlik P, Mosnier A, Leclere D, Kraksner F, Khabarov N, Obersteiner M (2015) Systems analysis of robust strategic decisions to plan secure food, energy, and water provision based on the stochastic GLOBIOM model. Cybern Syst Anal 51(1):125-133

Fang J, Liu G, Xu S (1996) Carbon reservoir of terrestrial ecosystem in China in Monitoring and relevant process of greenhouse gas concentration and emission (In Chinese). China Environmental Science Publishing House, Beijing

Fang J, Guo Z, Piao S, Chen A (2007) Terrestrial vegetation carbon sinks in China, 1981-2000. Sci China, Ser D Earth Sci 50(9):1341-1350

Fang J, Kato T, Guo Z, Yang Y, Hu H, Shen H, Zhao X, Kishimoto-Mo AW, Tang Y, Houghton RA (2014) Evidence for environmentally enhanced forest growth. Proc Natl Acad Sci 111(26):9527-9532

FAO (2019) Climate-smart agriculture and the Sustainable Development Goals: Mapping interlinkages, synergies and trade-offs and guidelines for integrated implementation, Rome

FAO and UNEP (2020) The State of the World's Forests 2020, Rome

Fricko O, Havlik P, Rogelj J, Klimont Z, Gusti M, Johnson N, Kolp P, Strubegger M, Valin H, Amann M (2017) The marker quantification of the Shared Socioeconomic Pathway 2: a middleof-the-road scenario for the 21st century. Glob Environ Chang 42:251-267

Fujimori S, Hasegawa T, Masui T, Takahashi K, Herran DS, Dai H, Hijioka Y, Kainuma M (2017) SSP3: AIM implementation of shared socioeconomic pathways. Glob Environ Chang $42: 268-283$

Geng X, Zhou X, Yin G, Hao F, Zhang X, Hao Z, Singh VP, Fu YH (2020) Extended growing season reduced river runoff in Luanhe River basin. J Hydrol 582:124538

Griggs D, Stafford-Smith M, Gaffney O, Rockström J, Öhman MC, Shyamsundar P, Steffen W, Glaser G, Kanie N, Noble I (2013) Policy: sustainable development goals for people and planet. Nature 495(7441):305

Harris F, Moss C, Joy EJ, Quinn R, Scheelbeek PF, Dangour AD, Green R (2020) The water footprint of diets: a global systematic review and meta-analysis. Adv Nutr 11(2):375-386

Hebei provincial bureau of statistics (2016) Hebei Economic Yearbook 2016, Hebei Provincial Statistics Bureau

Hebei Provincial Department of Land and Resources (2010) General Land Use Planning in Hebei Province (2006-2020) (in Chinese)

Hebei Provincial Department of Natural Resources (2018) Land greening planning of Hebei Province (2018-2035) (in Chinese)

Hewitt R, van Delden H, Escobar F (2014) Participatory land use modelling, pathways to an integrated approach. Environ Model Softw 52:149-165 
Hinson R, Lensink R, Mueller A (2019) Transforming agribusiness in developing countries: SDGs and the role of FinTech. Curr Opin Environ Sustain 41:1-9

Hou D, Bolan NS, Tsang DC, Kirkham MB, O'Connor D (2020) Sustainable soil use and management: an interdisciplinary and systematic approach. Sci Total Environ 729:138961

Hutton CW, Nicholls RJ, Lázár AN, Chapman A, Schaafsma M, Salehin M (2018) Potential trade-offs between the sustainable development goals in coastal Bangladesh. Sustainability 10(4):1108

Hyandye C, Martz LW (2017) A Markovian and cellular automata land-use change predictive model of the Usangu Catchment. Int J Remote Sens 38(1):64-81

Jacobsen D, Milner AM, Brown LE, Dangles O (2012) Biodiversity under threat in glacier-fed river systems. Nat Clim Chang 2(5):361-364

Jin D, Murray PJ, Xin X, Qin Y, Chen B, Qing G, Zhang Z, Yan R (2018) Attribution of explanatory factors for change in soil organic carbon density in the native grasslands of Inner Mongolia, China. J Arid Land 10(3):375-387

Jin X, Jiang P, Ma D, Li M (2019) Land system evolution of QinghaiTibetan Plateau under various development strategies. Appl Geogr 104:1-9

Ju XT, Kou CL, Christie P, Dou ZX, Zhang FS (2007) Changes in the soil environment from excessive application of fertilizers and manures to two contrasting intensive cropping systems on the North China Plain. Environ Pollut 145(2):497-506

Katila P, de Jong W, Galloway G, Pokorny B, Pacheco P (2017) Building on synergies: harnessing community and smallholder forestry for Sustainable Development Goals. 3902762756, International Union of Forest Research Organizations (IUFRO), Vienna, Austria

Kaye JP, Quemada M (2017) Using cover crops to mitigate and adapt to climate change. A review. Agron Sustain Dev 37(1):4

Krause T, Tilker A (2021) How the loss of forest fauna undermines the achievement of the SDGs. Ambio

Kriegler E, Bauer N, Popp A, Humpenöder F, Leimbach M, Strefler J, Baumstark L, Bodirsky BL, Hilaire J, Klein D (2017) Fossilfueled development (SSP5): an energy and resource intensive scenario for the 21st century. Glob Environ Chang 42:297-315

Kroll C, Warchold A, Pradhan P (2019) Sustainable Development Goals (SDGs): are we successful in turning trade-offs into synergies? Palgrave Commun 5(1):140

Kucsicsa G, Popovici E-A, Bălteanu D, Grigorescu I, Dumitraşcu M, Mitrică B (2019) Future land use/cover changes in Romania: regional simulations based on CLUE-S model and CORINE land cover database. Landscape Ecol Eng 15(1):75-90

Kuemmerle T, Erb K, Meyfroidt P, Müller D, Verburg PH, Estel S, Haberl H, Hostert P, Jepsen MR, Kastner T (2013) Challenges and opportunities in mapping land use intensity globally. Curr Opin Environ Sustain 5(5):484-493

Kurniawan A (2014) Spatio temporal analysis of land use change for supporting landslide exposure assessment. Indones J Geogr 46(2):104

Laborde D, Martin W, Swinnen J, Vos R (2020) COVID-19 risks to global food security. Science 369(6503):500-502

Lambin EF, Meyfroidt P (2011) Global land use change, economic globalization, and the looming land scarcity. Proc Natl Acad Sci 108(9):3465-3472

Landis JR, Koch GG (1977) The measurement of observer agreement for categorical data. Biometrics 33(1):159-174

Lehner B, Döll P, Alcamo J, Henrichs T, Kaspar F (2006) Estimating the impact of global change on flood and drought risks in Europe: a continental, integrated analysis. Clim Change 75(3):273-299

Li D, Wu S, Liu L, Liang Z, Li S (2017a) Evaluating regional water security through a freshwater ecosystem service flow model: A case study in Beijing-Tianjian-Hebei region, China. Ecol Ind 81:159-170

Li X, Chen G, Liu X, Liang X, Wang S, Chen Y, Pei F, Xu X (2017b) A new global land-use and land-cover change product at a 1-km resolution for 2010 to 2100 based on human-environment interactions. Ann Am Assoc Geogr 107(5):1040-1059

Lipper L, Thornton P, Campbell BM, Baedeker T, Braimoh A, Bwalya M, Caron P, Cattaneo A, Garrity D, Henry K, Hottle R, Jackson L, Jarvis A, Kossam F, Mann W, McCarthy N, Meybeck A, Neufeldt H, Remington T, Sen PT, Sessa R, Shula R, Tibu A, Torquebiau EF (2014) Climate-smart agriculture for food security. Nat Clim Chang 4(12):1068-1072

Liu J, Kuang W, Zhang Z, Xu X, Qin Y, Ning J, Zhou W, Zhang S, Li R, Yan C (2014) Spatiotemporal characteristics, patterns, and causes of land-use changes in China since the late 1980s. J Geog Sci 24(2):195-210

Liu J, Liu Q, Yang H (2016) Assessing water scarcity by simultaneously considering environmental flow requirements, water quantity, and water quality. Ecol Ind 60:434-441

Liu Z, Verburg PH, Wu J, He C (2017) Understanding land system change through scenario-based simulations: a case study from the drylands in northern China. Environ Manage 59(3):440-454

Lu R, Huang X, Zuo T, Xiao S, Zhao X, Zhang X (2009) Land use scenarios simulation based on CLUE-S and Markov Composite Model - a case study of Taihu Lake Rim in Jiangsu Province. Sci Geogr Sin 29:577-581

Luo Y, Li Q, Shen J, Wang C, Li B, Yuan S, Zhao B, Li H, Zhao J, Guo L (2019) Effects of agricultural land use change on organic carbon and its labile fractions in the soil profile in an urban agricultural area. Land Degrad Dev 30(15):1875-1885

Mackey B, DellaSala DA, Kormos C, Lindenmayer D, Kumpel N, Zimmerman B, Hugh S, Young V, Foley S, Arsenis K (2015) Policy options for the world's primary forests in multilateral environmental agreements. Conserv Lett 8(2):139-147

Malek Ž, Verburg PHR, Geijzendorffer I, Bondeau A, Cramer W (2018) Global change effects on land management in the Mediterranean region. Global Environ Change 50:238-254

Matthews RB, Gilbert NG, Roach A, Polhill JG, Gotts NM (2007) Agent-based land-use models: a review of applications. Landscape Ecol 22(10):1447-1459

Michalak AM (2016) Study role of climate change in extreme threats to water quality. Nature 535(7612):349-350

Milestad R, Svenfelt Å, Dreborg KH (2014) Developing integrated explorative and normative scenarios: the case of future land use in a climate-neutral Sweden. Futures 60:59-71

National Development and Reform Commission of China (2008) The national planning on medium- and long-term food security (2008-2020). China Financial and Economic Publishing House, Beijing, China

Nelson E, Mendoza G, Regetz J, Polasky S, Tallis H, Cameron D, Chan KM, Daily GC, Goldstein J, Kareiva PM (2009) Modeling multiple ecosystem services, biodiversity conservation, commodity production, and tradeoffs at landscape scales. Front Ecol Environ $7(1): 4-11$

Nerini FF, Tomei J, To LS, Bisaga I, Parikh P, Black M, Borrion A, Spataru C, Broto VC, Anandarajah G (2018) Mapping synergies and trade-offs between energy and the Sustainable Development Goals. Nat Energy 3(1):10-15

Nilsson M, Griggs D, Visbeck M (2016a) Policy: map the interactions between Sustainable Development Goals. Nature News 534(7607):320

Nilsson M, Griggs D, Visbeck M, Ringler C (2016b) A draft framework for understanding SDG interactions. International Paris

Nowak DJ, Crane DE, Stevens JC (2006) Air pollution removal by urban trees and shrubs in the United States. Urban Forestry Urban Greening 4(3-4):115-123 
O’Neill BC, Kriegler E, Riahi K, Ebi KL, Hallegatte S, Carter TR, Mathur R, van Vuuren DP (2014) A new scenario framework for climate change research: the concept of shared socioeconomic pathways. Clim Change 122(3):387-400

O'Neill BC, Tebaldi C, Van Vuuren DP, Eyring V, Friedlingstein P, Hurtt G, Knutti R, Kriegler E, Lamarque J-F, Lowe J (2016) The scenario model intercomparison project (ScenarioMIP) for CMIP6. Geosci Model Dev 9(9):3461-3482

Ornetsmüller C, Verburg PH, Heinimann A (2016) Scenarios of land system change in the Lao PDR: transitions in response to alternative demands on goods and services provided by the land. Appl Geogr 75:1-11

Palombi L, Sessa R (2013) Climate-smart agriculture: sourcebook. Climate-smart agriculture: sourcebook

Park J-Y, Park M-J, Joh H-K, Shin H-J, Kwon H-J, Srinivasan R, Kim S-J (2011) Assessment of MIROC3. 2 HiRes climate and CLUE$\mathrm{s}$ land use change impacts on watershed hydrology using SWAT. Transac ASABE 54(5):1713-1724

Parker DC, Hessl A, Davis SC (2008) Complexity, land-use modeling, and the human dimension: fundamental challenges for mapping unknown outcome spaces. Geoforum 39(2):789-804

Patel M, Kok K, Rothman DS (2007) Participatory scenario construction in land use analysis: an insight into the experiences created by stakeholder involvement in the Northern Mediterranean. Land Use Policy 24(3):546-561

Pereira LS, Cordery I, Iacovides I (2009) Coping with water scarcity: addressing the challenges. Springer Science \& Business Media

Ping F, Jianzhu L, Xian X (2008) Analysis of water resources trend and its causes of Panjiakou Reservoir (in Chinese). Geogr Res 27(1):213-220

Poggi F, Firmino A, Amado M (2018) Planning renewable energy in rural areas: impacts on occupation and land use. Energy 155:630-640

Popkin G (2019) How much can forests fight climate change? Nature 565(7737):280-283

Popp A, Calvin K, Fujimori S, Havlik P, Humpenöder F, Stehfest E, Bodirsky BL, Dietrich JP, Doelmann JC, Gusti M (2017) Landuse futures in the shared socio-economic pathways. Glob Environ Chang 42:331-345

Pradhan P, Costa L, Rybski D, Lucht W, Kropp JP (2017) A systematic study of sustainable development goal (SDG) interactions. Earth's Future 5(11):1169-1179

Rajib MA, Ahiablame L, Paul M (2016) Modeling the effects of future land use change on water quality under multiple scenarios: a case study of low-input agriculture with hay/pasture production. Sustain Water Quality Ecol 8:50-66

Robinson TP, Wint GW, Conchedda G, Van Boeckel TP, Ercoli V, Palamara E, Cinardi G, D’Aietti L, Hay SI, Gilbert M (2014) Mapping the global distribution of livestock. PLoS ONE 9(5):e96084

Rong K, Chen X, Liu M, Lin W, Gao Y (2009) Simulation of the effect of land use/cover change on non-point source pollution load in Xixi watershed of the Jinjiang Basin with SWAT Model. J AgroEnviron Sci 28:1488-1493

Rosegrant MW, Ringler C, Zhu T (2009) Water for agriculture: maintaining food security under growing scarcity. Ann Rev Environ Resour 34:205-222

Sayer J, Sheil D, Galloway G, Riggs RA, Mewett G, MacDicken KG, Arts B, Boedhihartono AK, Langston J, Edwards DP (2019) SDG 15: life on land-The Central role of forests in sustainable development. In: Sustainable development goals: their impacts on forests and people. Cambridge University Press, Cambridge

Scherer L, Behrens P, de Koning A, Heijungs R, Sprecher B, Tukker A (2018) Trade-offs between social and environmental Sustainable Development Goals. Environ Sci Policy 90:65-72
Seymour F, Busch J (2016) Why forests? Why now?: The science, economics, and politics of tropical forests and climate change. Brookings Institution Press, Washington, DC, USA

Sharp R, Tallis HT, Ricketts T, Guerry AD, Wood SA, Chaplin-Kramer R, Nelson E, Ennaanay D, Wolny S, Olwero N, Vigerstol K, Pennington D, Mendoza G, Aukema J, Foster J, Forrest J, Cameron D, Arkema K, Lonsdorf E, Kennedy C, Verutes G, Kim CK, Guannel G, Papenfus M, Toft J, Marsik M, Bernhardt J, Griffin R, Glowinski K, Chaumont N, Perelman A, Lacayo M, Mandle L, Hamel P, Vogl AL, Rogers L, Bierbower W, Denu D, Douglass J (2020) InVEST 3.8.0. User's Guide, The Natural Capital Project, Stanford University, University of Minnesota, The Nature Conservancy, and World Wildlife Fund, The Natural Capital Project, Stanford University, University of Minnesota, The Nature Conservancy, and World Wildlife Fund

Sharps K, Masante D, Thomas A, Jackson B, Redhead J, May L, Prosser H, Cosby B, Emmett B, Jones L (2017) Comparing strengths and weaknesses of three ecosystem services modelling tools in a diverse UK river catchment. Sci Total Environ 584:118-130

Singh GG, Cisneros-Montemayor AM, Swartz W, Cheung W, Guy JA, Kenny T-A, McOwen CJ, Asch R, Geffert JL, Wabnitz CC (2018a) A rapid assessment of co-benefits and trade-offs among Sustainable Development Goals. Mar Policy 93:223-231

Singh SK, Laari PB, Mustak S, Srivastava PK, Szabó S (2018b) Modelling of land use land cover change using earth observation datasets of Tons River Basin, Madhya Pradesh, India. Geocarto Int 33(11):1202-1222

Sinha A, Sengupta T, Alvarado R (2020) Interplay between technological innovation and environmental quality: formulating the SDG policies for next 11 economies. J Clean Prod 242:118549

Sohl TL, Sayler KL, Drummond MA, Loveland TR (2007) The FORESCE model: a practical approach for projecting land cover change using scenario-based modeling. J Land Use Sci 2(2):103-126

State Forestry Administration of China (2016) National Forest Management Planning (2016-2050) (in Chinese). China Forestry Publishing House, Beijing, China

State Forestry Administration of China (2019) Implementation plan of afforestation in Zhangjiakou city and Chengde Bashang area of Hebei Province (in Chinese). China Forestry Publishing House, Beijing, China

Strengers B, Leemans R, Eickhout B, de Vries B, Bouwman L (2004) The land-use projections and resulting emissions in the IPCC SRES scenarios scenarios as simulated by the IMAGE 2.2 model. GeoJournal 61(4):381-393

Tang X, Zhao X, Bai Y, Tang Z, Wang W, Zhao Y, Wan H, Xie Z, Shi X, Wu B (2018) Carbon pools in China's terrestrial ecosystems: new estimates based on an intensive field survey. Proc Natl Acad Sci 115(16):4021-4026

The Lancet Public H (2020) Will the COVID-19 pandemic threaten the SDGs? Lancet Public Health 5(9):e460

Tsiafouli MA, Thébault E, Sgardelis SP, De Ruiter PC, Van Der Putten WH, Birkhofer K, Hemerik L, De Vries FT, Bardgett RD, Brady MV (2015) Intensive agriculture reduces soil biodiversity across Europe. Glob Change Biol 21(2):973-985

Turner B (1997) The sustainability principle in global agendas: implications for understanding land-use/cover change. Geograph J 163(2):133-140

UNDP (2015) Sustainable development goals (SDGs). UNDP, USA

van Asselen S, Verburg PH (2012) A land system representation for global assessments and land-use modeling. Glob Change Biol 18(10):3125-3148

van Vliet J, Bregt AK, Hagen-Zanker A (2011) Revisiting Kappa to account for change in the accuracy assessment of land-use change models. Ecol Model 222(8):1367-1375 
van Vliet MT, Franssen WH, Yearsley JR, Ludwig F, Haddeland I, Lettenmaier DP, Kabat P (2013) Global river discharge and water temperature under climate change. Glob Environ Chang 23(2):450-464

Van Asselen S, Verburg PH (2013) Land cover change or land-use intensification: simulating land system change with a globalscale land change model. Glob Change Biol 19(12):3648-3667

Van Vuuren DP, Kriegler E, O’Neill BC, Ebi KL, Riahi K, Carter TR, Edmonds J, Hallegatte S, Kram T, Mathur R (2014) A new scenario framework for climate change research: scenario matrix architecture. Clim Change 122(3):373-386

Van Vuuren DP, Stehfest E, Gernaat DE, Doelman JC, Van den Berg M, Harmsen M, de Boer HS, Bouwman LF, Daioglou V, Edelenbosch OY (2017) Energy, land-use and greenhouse gas emissions trajectories under a green growth paradigm. Glob Environ Chang 42:237-250

van de Ven D-J, Capellan-Peréz I, Arto I, Cazcarro I, de Castro C, Patel P, Gonzalez-Eguino M (2021) The potential land requirements and related land use change emissions of solar energy. Sci Rep 11(1):2907

Verburg P, Overmars K (2007) Dynamic simulation of land-use change trajectories with the CLUE-s model, modelling landuse change. Springer, pp 321-337

Verburg PH, Veldkamp A (2004) Projecting land use transitions at forest fringes in the Philippines at two spatial scales. Landscape Ecol 19(1):77-98

Verburg PH, Soepboer W, Veldkamp A, Limpiada R, Espaldon V, Mastura SS (2002) Modeling the spatial dynamics of regional land use: the CLUE-S model. Environ Manage 30(3):391-405

Verburg PH, Schot PP, Dijst MJ, Veldkamp A (2004) Land use change modelling: current practice and research priorities. GeoJournal 61(4):309-324

Verburg PH, Ellis EC, Letourneau A (2011) A global assessment of market accessibility and market influence for global environmental change studies. Environ Res Lett 6(3):034019

Vörösmarty CJ, McIntyre PB, Gessner MO, Dudgeon D, Prusevich A, Green P, Glidden S, Bunn SE, Sullivan CA, Liermann CR (2010) Global threats to human water security and river biodiversity. Nature 467(7315):555-561

Walsh PP, Murphy E, Horan D (2020) The role of science, technology and innovation in the UN 2030 agenda. Technol Forecast Soc Chang 154:119957

Wang C, Gao H (2009) Carbon-sink function of artificial Larix principis-rupprechtii plantation (in Chinese). Chin J Eco-Agric 17(4):756-759

Wu Y, Zhang X, Fu Y, Hao F, Yin G (2020) Response of vegetation to changes in temperature and precipitation at a semi-arid area of Northern China based on multi-statistical methods. Forests 11(3):340

Xi X, Yang Z, Liao Q, Zhang J, Bai R, Zhang X, Jin L, Wang H, Li M, Xia X (2010) Soil organic carbon storage in typical regions of China (in Chinese). Quaternary Sci 30(3):573-583

Xiao D, Niu H, Guo J, Zhao S, Fan L (2021) Carbon Storage change analysis and emission reduction suggestions under land use transition: a case study of Henan Province, China. Int J Environ Res Public Health 18(4): 1844

Xin Y, Tao F (2021) Have the agricultural production systems in the North China Plain changed towards to climate smart agriculture since 2000? J Clean Prod 299:126940
Xu L, Yu G, He N, Wang Q, Gao Y, Wen D, Li S, Niu S, Ge J (2018a) Carbon storage in China's terrestrial ecosystems: a synthesis. Sci Rep 8(1):1-13

Xu X, Liu J, Zhang S, Li R, Yan C, Wu S (2018b) China's MultiPeriod Land Use Land Cover Remote Sensing Monitoring Data Set (CNLUCC). Resource and Environment Data Cloud Platform: Beijing, China

Xu J, Barrett B, Renaud F (2021) Ecosystem services and disservices in the Luanhe River Basin in China under past, current and future land uses: implications for the Sustainable Development Goals. Sustainability Science, forthcoming

Yang W, Long D, Bai P (2019) Impacts of future land cover and climate changes on runoff in the mostly afforested river basin in North China. J Hydrol 570:201-219

Zhang Q (2009) The south-to-north water transfer project of China: environmental implications and monitoring strategy 1. J Am Water Resour Assoc 45(5):1238-1247

Zhang X, Xu Y, Hao F, Li C, Wang X (2019) Hydrological components variability under the impact of climate change in a semi-arid river basin. Water 11(6):1122

Zhao X, Xue J-F, Zhang X-Q, Kong F-L, Chen F, Lal R, Zhang H-L (2015) Stratification and storage of soil organic carbon and nitrogen as affected by tillage practices in the North China Plain. PLoS ONE 10(6):e0128873

Zhao Z, Cai M, Wang F, Winkler JA, Connor T, Chung MG, Zhang J, Yang H, Xu Z, Tang Y, Ouyang Z, Zhang H, Liu J (2021) Synergies and tradeoffs among Sustainable Development Goals across boundaries in a metacoupled world. Sci Total Environ $751: 141749$

Zhen L, Ishwaran N, Luo Q, Wei Y, Zhang Q (2020) Role and significance of restoration technologies for vulnerable ecosystems in building an ecological civilization in China. Environ Dev 34:100494

Zhou F, Xu Y, Chen Y, Xu C-Y, Gao Y, Du J (2013) Hydrological response to urbanization at different spatio-temporal scales simulated by coupling of CLUE-S and the SWAT model in the Yangtze River Delta region. J Hydrol 485:113-125

Zhou Y, Khu S-T, Xi B, Su J, Hao F, Wu J, Huo S (2014) Status and challenges of water pollution problems in China: learning from the European experience. Environ Earth Sci 72(4):1243-1254

Zhou X, Moinuddin M, Xu Z (2017) Sustainable development goals interlinkages and network analysis: a practical tool for SDG integration and policy coherence. Institute for Global Environmental Strategies (IGES), Kanagawa, Japan

Zhou X, Moinuddin M, Renaud F, Barrett B, Xu J, Liang Q, Zhao J, Xia X, Bosher L, Huang S, Hoey T (2021) Development of an SDG interlinkages analysis model at the river basin scale: a case study in the Luanhe River Basin, China. Sustainability Science, forthcoming

Zhu X, Liu W, Jiang XJ, Wang P, Li W (2018) Effects of land-use changes on runoff and sediment yield: implications for soil conservation and forest management in Xishuangbanna, Southwest China. Land Degradation Dev 29(9):2962-2974

Publisher's Note Springer Nature remains neutral with regard to jurisdictional claims in published maps and institutional affiliations. 